\title{
A Contribution to our Knowledge of Rachiopteris cylindrica, Will.
}

\author{
BY
}

\section{N. BANCROFT.}

With Plates XXVI and XXVII and seventeen Figures in the Text

\section{Contents.}

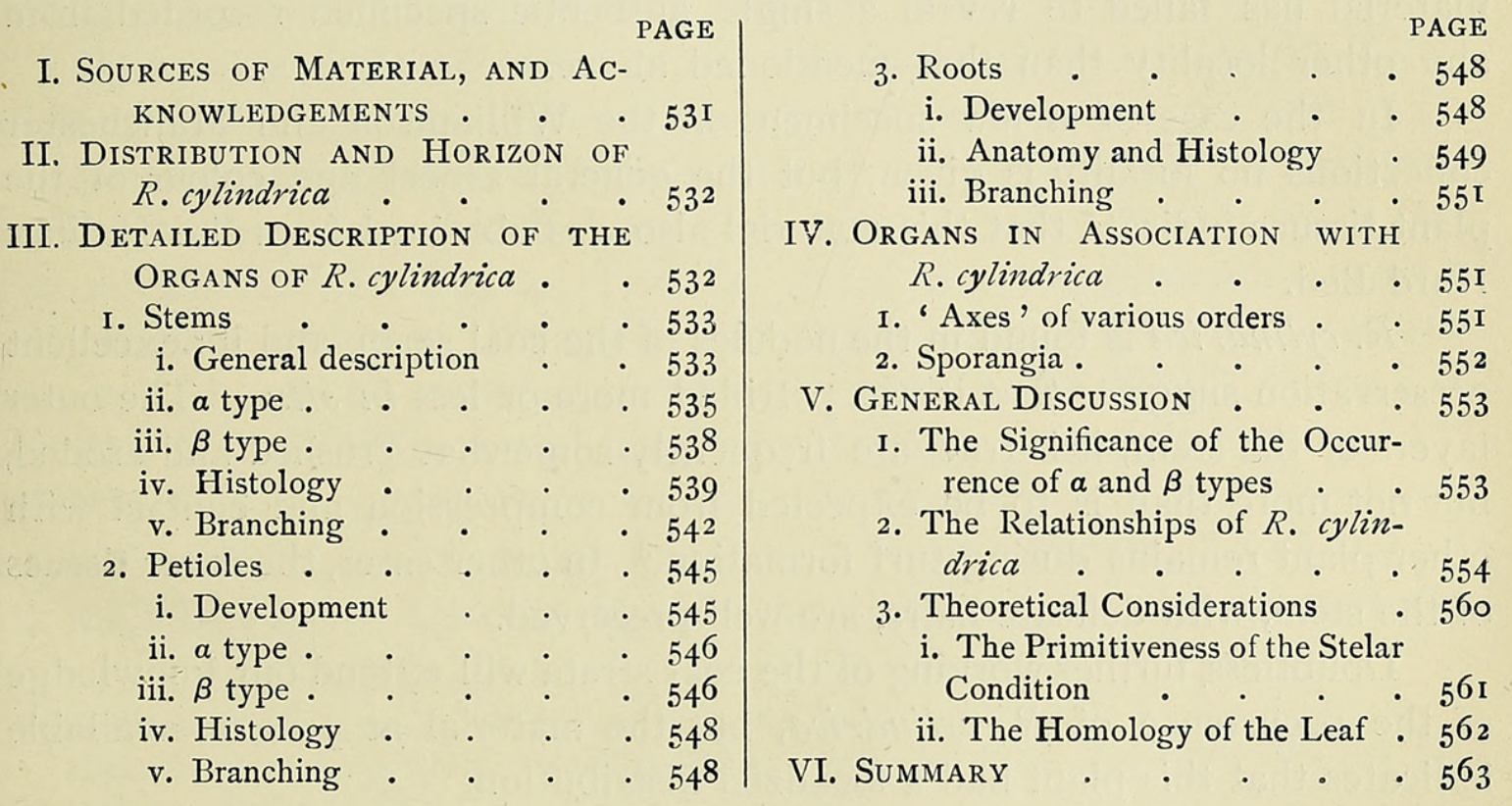

\section{Sources of Material, and AcKnowledgements.}

THE series of preparations of Rachiopteris cylindrica upon which 1 the following description is mainly based, were handed to the writer by Prof. F. W. Oliver, to whom grateful acknowledgements are due, not only for the material, but for the opportunity to carry out this investigation at University College, London.

The writer also desires to thank Prof. F. E. Weiss, through whose kindness some valuable evidence has been obtained from the slides of the Cash and other collections, at Manchester University; Dr. A. Smith Woodward, for permission to examine and make drawings from the Williamson and General collections, at the British Museum; Prof. A. C. Seward and Dr. E. A. N. Arber, for similar opportunities with regard to 
the Botany School and Binney collections, at Cambridge; Dr. W. T. Gordon, for the loan of slides, and for helpful discussion; Miss T. L. Prankerd, for very kindly lending preparations and material of Hottonia palustris and H. inflata; and other friends who have supplied literature, and material of recent plants for comparative purposes.

\section{Distribution and Horizon of $R$. cylindrica.}

The distribution of Rachiopteris cylindrica appears to be restricted to the Halifax-Huddersfield area, where it occurs in the Halifax Hard Bed of Lower Coal Measure Age. ${ }^{1}$

Williamson, who originally described the species in 1878,2 remarked that he had never discovered it in the Oldham nodules; and a search through various collections comprising both old and recently acquired material has failed to reveal a single authentic specimen recorded from any other locality than that mentioned above.

In the case of a few specimens in the Williamson and Manchester collections no locality is given, but the general aspect and colour of the plant tissues indicate that this material also was obtained from the Halifax Hard Bed.

R. cylindrica is found in the nodules of the coal seam, and its excellent preservation suggests that it was petrified more or less in situ. The outer layers of the stem, it is true, are frequently somewhat crushed and eroded, but not more than is to be expected from compression and contact with other plant remains during turf formation. ${ }^{3}$ In other cases, the outer tissues of the stem, with delicate hairs, are well preserved.

Doubtless, further working of the coal strata will extend our knowledge of the occurrence of $R$. cylindrica, but the material at present available indicates that this plant had a localized distribution.

\section{Detailed Description of the Organs of $R$. cylindrica.}

An idea as to the structure and morphology of Rachiopteris cylindrica is drawn from the certain evidence of direct connexion between stems, roots, and primary petioles; and from the suggestive evidence of more or less constantly associated axial structures, and sporangia of Fern type. The first class of evidence, owing to the favourable preservation of the material, may be considered in detail.

${ }^{1}$ See Geological Ordnance Survey Map, No. 88 N.E.

2 Williamson, W. C. : On the Organization of the Fossil Plants of the Coal Measures. Pt. ix, Phil. Trans. Roy. Soc., B, vol. I69, I878, p. 319. See p. 351.

3 Stopes, M. C., and Watson, D. M. S. : On the Present Distribution and Origin of the Calcareous Concretions in Coal Seams, known as 'Coal Balls'. Phil. Trans. Roy. Soc., B, vol. 200, I908, p. 167 . See p. I73 


\section{Stems. ${ }^{1}$}

i. General description:-An examination of the serial sections of $R$. cylindrica gives the impression of a slender plant, the stems of which may have been prostrate upon the ground, or semi-erect, supporting themselves upon the surrounding vegetation. ${ }^{2}$ These stems branched dichotomously $^{3}$ (P1. XXVI, Figs. 5, 8, 9; Text-figs. I, 7, 8) or produced leaves ${ }^{4}$ (Pl. XXVI, Figs. 6 and 9; Text-figs. 8 and 9) at variable but fairly infrequent intervals, so that the habit of the plant must have been somewhat lax. ${ }^{5}$ (See Text-figs. I and 8 , in which the length of stem represented is indicated.) The relation of leaf production to dichotomy is variable; usually there is an interval between the two processes, although a leaf may occur in close association with a branch, as shown in Text-fig. 8 .

Slender roots occur--usually singly - at or near the points of branching or leaf production (Pl. XXVI, Figs. 8 and 3).

The stems of $R$. cylindrica are circular in transverse section (P1. XXVI, Figs. 2, 3, and 4), their average diameter being from 2 to $2.5 \mathrm{~mm}$. The single central stele possesses a cylindrical core of wood (Pl. XXVI, Figs. I-4), surrounded by phloem, in which the sieve-tubes are often distinct (Pl. XXVI, Fig. 2; Pl. XXVII, Fig. 4; Text-fig. 5); a somewhat irregular layer of cells, usually darkened, separates the stelar tissues from those of the cortex, and may be considered as an endodermis (Pl. XXVI, Fig. I ; P1. XXVII, Fig. 4). The wood may have a single protoxylem group ${ }^{6}$ (Pl. XXVI, Figs. 2, 3, and 7), in which case the structure is centrarch, or typically endarch; or there are from two to five groups (Pl. XXVI, Fig. I ; Pl. XXVII, Fig. 4 ; Text-fig. 2), when the structure tends towards mesarchy,

1 For previous references see-

Williamson ('78), pp. 350, 35I ; P1. 24, Figs. 80-88.

Hick, T.: On Rachiopteris cylindrica, Will. Mem. and Proc. Manchester Lit. and Phil. Soc., vol. 4I, I 896 , p. I, Pl. I.

Tansley, A. G. : Lectures on the Evolution of the Filicinean Vascular System. New Phyt., Reprint, 1908. See p. 14 and Fig. 4.

Browne, Isabel: The Phylogeny and Inter-relationships of the Pteridophyta. New Phyt., Reprint, I908. See p. 57 .

Scott, D. H. : Studies in Fossil Botany. Second Edition, I908. See p. 333.

Seward, A. C. : Fossil Plants, vol. 2, I9ro. See pp. $43^{8-40}$ and Fig. 305.

2 See p. 554 .

3 This term is used provisionally and in a purely descriptive sense ; as Dr. Lang has pointed out to the writer, it may be necessary to modify our views with regard to apparent dichotomy in these forms.

4 Throughout the following account, the acropetal method of description is adopted, as being, in this case, the most convenient; see Boodle, L. A. : On Descriptions of Vascular Structures. New Phyt., vol. 2, I903, p. 107. This author justifies the use of the acropetal method in descriptions of 'ferns, which have a solid cauline stele, or in which there are no leaf-traces showing distinct individuality in the internode', for ' in this way it is clearly seen what part of the stele is continuous with the leaf-trace' (p. 108).

5 Tansley ('08), p. I5; Scott ('08), p. 333.

6 That is, a group of small elements suggesting protoxylem; they do not seem to possess the typical annular or spiral thickenings. 


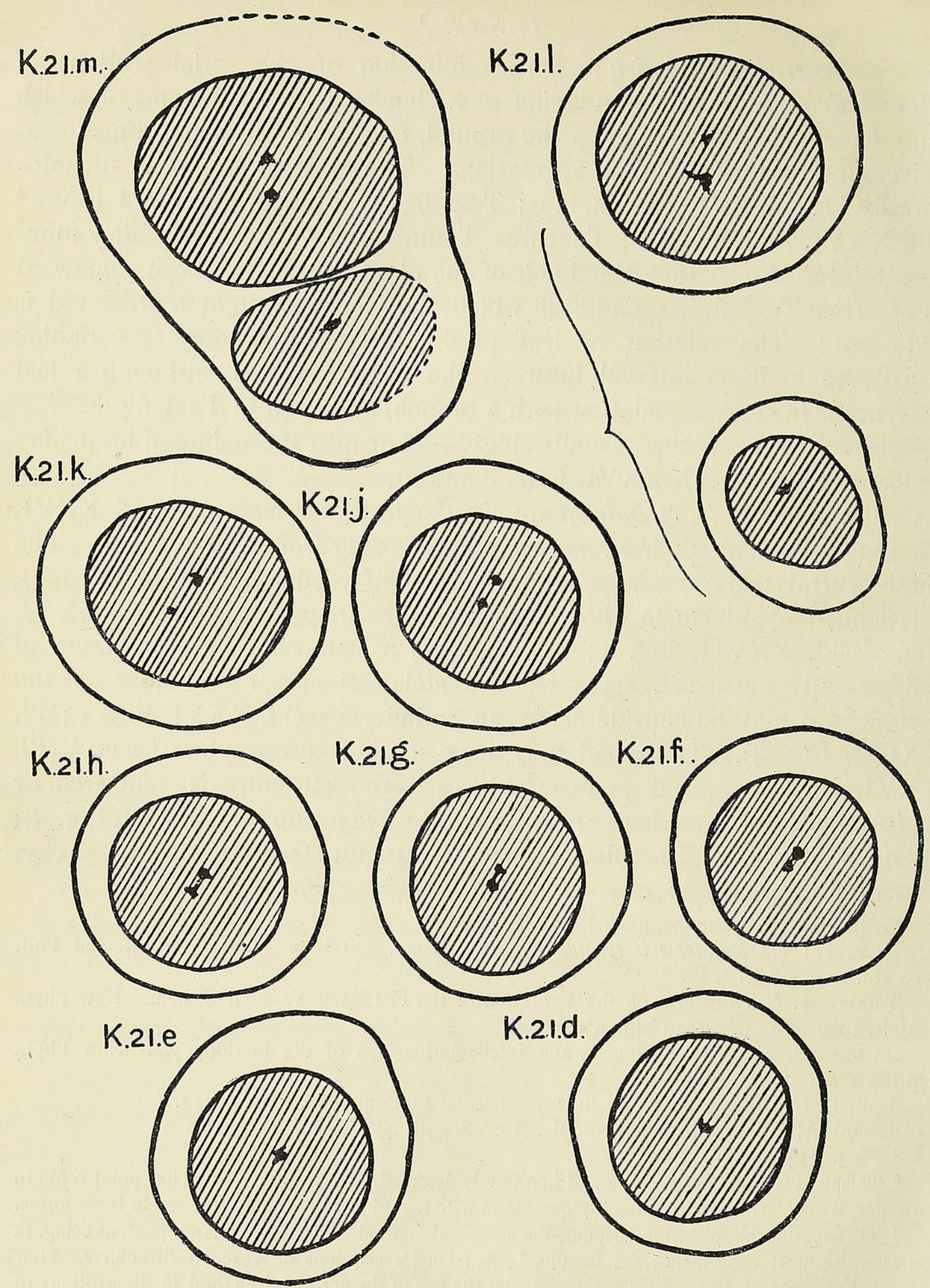

Text-FIG. I. Diagrams of the stele; a series of sections taken through about I inch of an $a$ stem, showing the occurrence of the centrarch condition above a place of branching. $\mathrm{K} 2 \mathrm{I} k-$ $\mathrm{K} 2 \mathrm{I} d$ represent the larger of the two steles in $\mathrm{K}_{2 \mathrm{I}} m$ and $\mathrm{K} 2 \mathrm{I} l$, and show that the two original protoxylem groups fuse to form a single endarch strand. In this and other diagrams the xylem is shaded, and the protoxylem strands are indicated by black dots; a broken line represents a restored outline. $\times 35$. (From series K 2 I, stem B, University College, London.) 
the groups being arranged round the centre, sometimes at considerable distances from it. ${ }^{1}$ The stele is surrounded by a cortex, usually showing inner, middle, and outer regions (Pl. XXVI, Figs. I and 2); the epidermal layer, when not crushed, is seen to bear numerous unicellular, or typically multicellular hairs, often with somewhat rounded terminal cells (Text-fig. 4).

This general description applies to all stems referred to $R$. cylindrica; the stems, however, fall into two distinct groups, representative types of which will be described respectively as ' $\alpha$ ' and ' $\beta$ '. A discussion as to the significance of these two types will follow in Section $\mathrm{V}^{2}{ }^{2}$

ii. a type. ${ }^{3}$-The stems belonging to this group are characterized by the possession of large xylem strands, the average diameter of which is $0.7 \mathrm{~mm}$. There are typically several ( $\mathrm{two}$, or, more commonly, from three to five) protoxylem groups arranged round the centre (Pl. XXVI, Fig. I); the centrarch condition with one protoxylem group occurs (Pl. XXVI, Fig. 2), but it is comparatively rare, and results from the fusion of two or more groups (Text-fig. I). The normal condition in stems of $a$ type thus tends towards mesarchy, for the occurrence of more than two protoxylem groups is quite independent of branching, ${ }^{4}$ as an examination of serial sections demonstrates (Text-fig. 7).

The great interest of this type lies in the fact that the mesarch condition is accompanied in many cases by a certain amount of differentiation of the xylem ${ }^{5}$ into an outer zone in which the lumen of the tracheides is of ordinary size ( $100 \mu$ in diameter), and an inner solid core, in which the tracheides are much narrower (Text-fig. 2; Pl. XXVI, Fig. I). There are no parenchymatous cells interspersed among the tracheides. ${ }^{6}$ The differentiation of the wood is particularly marked in the larger stems (Text-fig. 2), transverse sections of which recall the condition seen in Diplolabis Römeri. ${ }^{7}$ The protoxylem groups are situated at the junction of the wide and narrow elements (Text-fig. 2), as in Diplolabis. The size of the core of small elements is very variable (cf. Pl. XXVI, Fig. I, and Text-fig. 2); it is dependent on the size of the xylem strand as a whole, on the number of protoxylem groups present, and on their distance from the centre of the strand.

1 With regard to this point, cf. the statements of Williamson ('78), p. $35^{\circ}$; Hick ('96), p. 8 ; Tansley ('08), p. I5; Scott ('08), p. 333 ; Brown ('08), p. 57 ; Seward ('10), p. $43^{8}$. The general view is that $R$. cylindrica is typically endarch; Hick noted the frequent presence of four or five protoxylem groups arranged symmetrically round the centre of the stele, but Lady Isabel Browne was the first author to comment upon this tendency towards mesarchy.

${ }^{2}$ p. 553 .

3 Williamson based his original description upon this type: ('78), p. 350, P1. 24, Figs. 80 and 87 .

4 Cf. Browne ('08), p. 57 .

5 Gordon, W. T. : On the Relation between the Fossil Osmundaceae and the Zygopterideae. Proc. Cambridge Phil. Soc., vol. 15, Pt. V, I910, p. 398. See p. 400.

6 Hick ('96), p. 9.

7 Gordon, W. T. : On the Structure and Affinities of Diplolabis Römeri (Solms). Trans. Roy. Soc. Edin., vol. 47, Pt. IV, I9II, p. 7II. See p. 7I9. 
Stems of $a$ type are further characterized by the structure of the cortex, which presents three areas, though these are not always distinctly recognizable, owing to the tendency of the outer cortex to become crushed and eroded (Pl. XXVI, Figs. I and 2).

The cells composing from three to six of the innermost cortical layers are somewhat rectangular and tangentially elongated as seen in transverse section. They have thick walls, and the layers are often arranged more or less concentrically ${ }^{1}$ in a manner more characteristic of roots than of stems (Pl. XXVI, Figs. I and 2).

The inner cortex passes gradually into the middle cortex, in which the

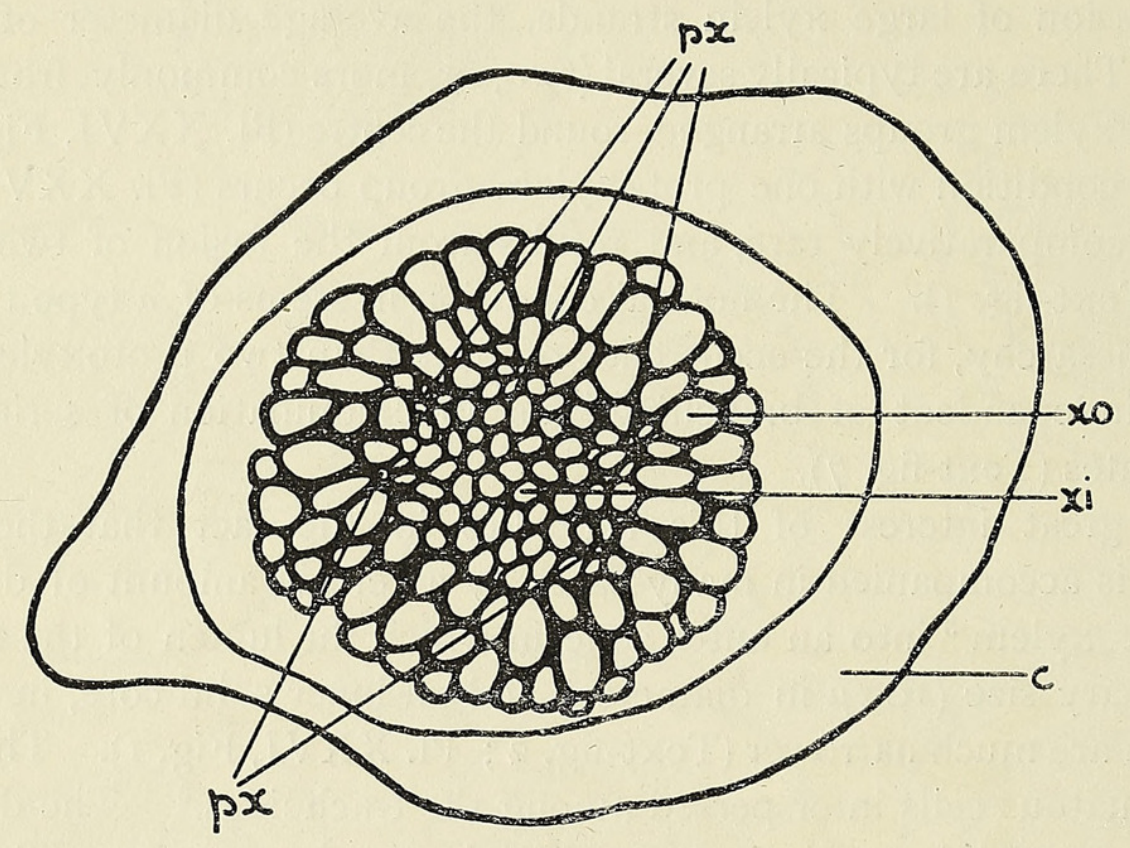

TExT-FIg. 2. A large $a$ stem, in which the xylem is shown in detail. Note the distinct differentiation of the xylem into large outer $(x o$.$) , and small inner (x i$.$) tracheides. There are five$ groups of tracheides $(p x$. $)$ suggesting protoxylem, situated at the junction of the outer and inner wood. The cortical layers $(c$.$) of this stem are much crushed. \quad \times 40$. (From slide I 552, Williamson collection.)

cells are rather loosely arranged and are more rounded in transverse section than those of the preceding area (Pl. XXVI, Figs. I and 2). They are irregular in size, and the thickness of their walls is slightly variable in different specimens.

The outer cortex is composed of from four to twelve layers of fairly large thin-walled cells (Text-fig. 3), and is thus markedly distinct from the middle cortex, forming a delicate tissue which is usually more or less crushed, so that the form of the component cells is unrecognizable (Pl. XXVI, Figs. I and 2). The appearance of this zone suggests that it may have formed an assimilatory tissue comparable with that of the stems of Psilotum, or the rachis of Stauropteris. ${ }^{2}$ Occasionally the whole of the

1 Williamson ('78), p. 350; Hick ('96), p. 3 .

2 Scott, D. H. : The Sporangia of Stauropteris oldhamia. New Phyt., vol. 4, I905, p. II4. See p. I I 5 .

Bertrand, P. : Études sur la Fronde des Zygoptéridées. Lille, I909. See P1. VII, Fig. 48. 
outer cortex appears to be obliterated, and in these cases, the cortex as a whole presents a fairly uniform appearance, the rounded cells of the middle cortex being the most conspicuous feature.

In longitudinal section the inner and middle cortical cells are elongated, their end walls being straight or oblique; no specimen has been obscrved which gives a clear idea of the outer cortical cells in longitudinal section.

In some specimens large cavities occur here and there in the outer cortex and particularly where this adjoins the middle cortex (Pl. XXVI, Figs. I and 5). Their general appearance suggests that they may have been secretory in function, though no trace of contents has been observed. On

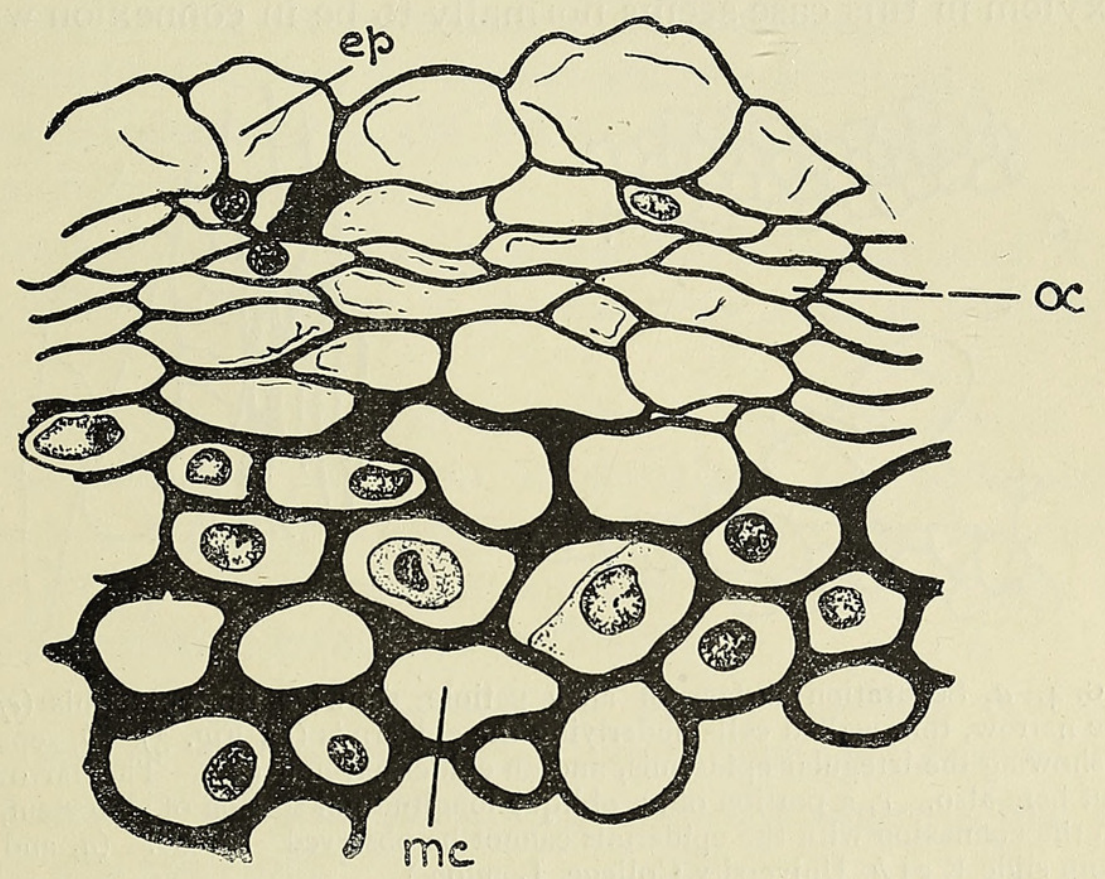

TEXT-FIG. 3. The outer layers of an $\alpha$ stem, just above a branch, showing the thin-walled cells of the outer cortex $(o c$.$) , and the irregular epidermal cells (e p$.$) still uncrushed ; m c$., middle cortical cells. $\times 400$. (From slide $\mathrm{K} 20 \mathrm{~m}$, University College, London.)

the other hand, they may merely be due to breaking down of the cells before or during petrifaction.

The epidermal cells are rarely recognizable ${ }^{1}$ in stems of a type. In some cases, however, at a place of branching, the structure of the epidermis is well shown on the inner or 'separation' surface of both products of stem division (Text-fig. $4, a$ and $b$ ). The epidermal cells are large and rather irregular in shape, as seen in transverse section, while in longitudinal section they appear to be slightly elongated ; frequently they produce multicellular hairs (Text-fig. $4, b$ and $c$ ).

A point of interest is the absence of the thin-walled cortical cells under the epidermis, in the region just above the separation of a branch (Textfig. $4, a$ and $b$ ). These seem to develop gradually, becoming intercalated between the thicker-walled cells and the epidermis. Text-fig. 3 shows

\section{Hick ('96), p. 2.}

$\mathrm{N} \cap 2$ 
a stage in the production of the outer cortex just above branch separation. The large-celled epidermis is still distinct at this point; no traces of stomata have been observed.

iii. $\beta$ type.-The stems of $R$. cylindrica described and figured by Hick are, with one exception, referable to this type ${ }^{1}$; the occurrence of the two forms is not specially mentioned by this author. ${ }^{2}$

Stems of $\beta$ type are similar in size to those of $a$ type, but are distinguished from them by the relatively small size of the cylindrical xylem strand, of which the average diameter is $0.4 \mathrm{~mm}$. This strand typically possesses a single central protoxylem group, so that a condition of true endarchy is realized (P1. XXVI, Figs. 3 and 7). The occurrence of more than one protoxylem in this case seems normally to be in connexion with branch-
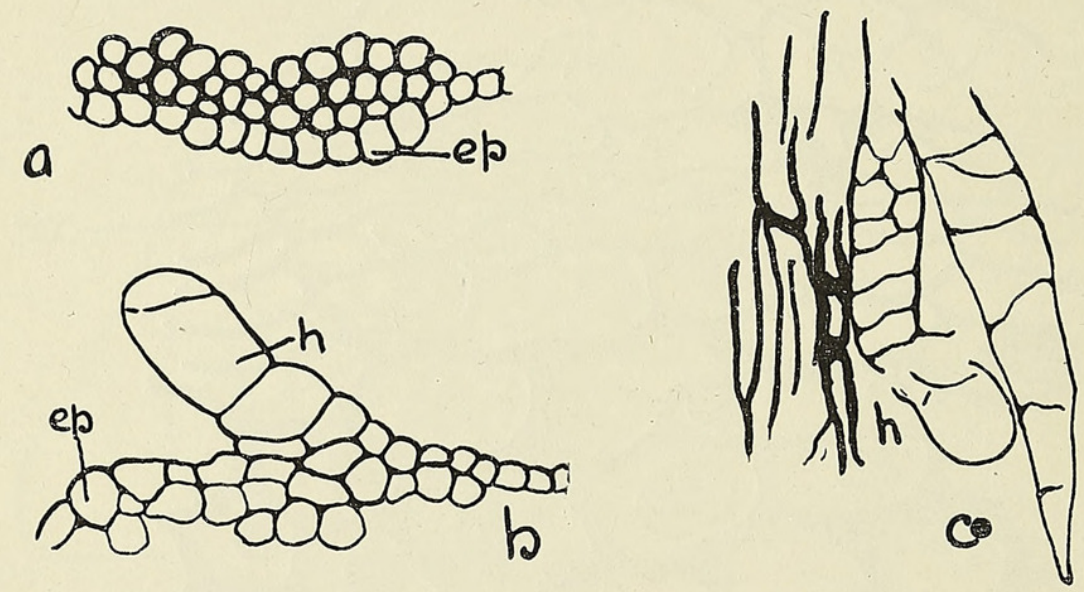

TEXT-FIG. 4. $a$, Separation surface of an $a$ petiole, showing the epidermis (ep.). Note the absence of the narrow, thin-walled cells underlying the epidermis (cf. Fig. 3). b, separation surface of an $a$ stem, showing the irregular epidermis, and an epidermal hair $\left(h_{0}\right)$. The narrow, thin-walled cells are absent here also. $c$, a portion of an oblique longitudinal section of an $a$ stem, showing two hairs of which the connexion with the epidermis cannot be observed. $\times 80 . \quad(a$, and $b$, from slide $\mathrm{K} 20 \mathrm{~m}$; $c$, from slide $\mathrm{K} 2 \mathrm{I} h$, University College, London.)

ing (Text-fig. 8); and apart from the narrow elements of the protoxylem group, there is no differentiation in size between central and outer tracheides. The elements are all of the type of the outer tracheides in $a$ stems, although they are less in diameter $(70 \mu)$ (cf. Pl. XXVI, Figs. I and 8).

The three cortical areas are again distinguishable in $\beta$ type stems. ${ }^{3}$

The inner cortex is composed of two or three series of tangentially elongated cells (Pl. XXVI, Figs. 3, 8, and 9), the walls of which are firm but not thickened to any extent. There is a varying tendency towards concentric arrangement of the inner cell-series, and the gradual transition to the middle cortex takes place as in a stems.

The middle cortex consists of rounded or polygonal cells, thin-walled, and somewhat irregular in size. Near the inner limit of this area is a band

1 Hick ('96): the exception is figured in Pl. I, Fig. 5.

2 Williamson figures and notes the two forms of stem; his Fig. 88 is a $\beta$ type stem.

3 Cf. Hick's description ('96), p. 4 . 
consisting of several cell-layers in which the elements are small and very loosely arranged (Pl. XXVI, Figs. 3 and 8). In some specimens this band of cells has become crushed (Pl. XXVI, Fig. 9), in others it has given rise to radial lacunae (PI. XXVI, Fig. 4), the presence of which was noted and figured by Hick. ${ }^{1}$ Beyond the lacunae, the cells of the middle cortex are larger, and tend to become somewhat radially elongated (Pl. XXVI, Figs. 3 and 7); the outermost cells of this area have slightly thickened walls (Pl. XXVI, Figs. 3, 4, and 7).

The outer cortical cells are apparently of the same type as those of $a$ stems (Pl. XXVI, Fig. 8), although they are usually much more crushed. Occasionally the epidermis, with numerous hairs, may be observed, but in these cases the thin-walled cortex is not developed.

In longitudinal section the thicker-walled cortical cells are elongated; the thin-walled elements of the middle cortex are shorter, having their end walls more or less horizontal.

iv. Histology.-The unusually favourable preservation of R. cylindrica permits a fuller investigation of its histology than is possible in many cases.

The details of cell structure in $a$ and $\beta$ stems are similar. The long, pointed tracheides are pitted on all surfaces; and while the narrower walls present a typically scalariform appearance, the broader walls are reticulately pitted. The arrangement and extent of the pits may occasionally be observed in transverse section. ${ }^{2}$

The smaller tracheides, considered as representing protoxylem elements, are usually pitted in a scalariform manner, ${ }^{3}$ instead of showing the typical annular or spiral thickening; this fact suggests that the growth of the stems was not rapid. ${ }^{4}$

There are a few scattered cells of xylem parenchyma, often with their contents preserved, and a continuous zone of phloem surrounds the xylem strand (Text-fig. 5). The phloem typically consists of a layer of large sieve-tubes accompanied on either side by narrow cells of phloem parenchyma. The sieve-tubes usually form a single series, and are as distinct in transverse section (Text-fig. 5, st.; Pl. XXVII, Fig. 4) as the corresponding elements in a living Fern, such as Pteridium or Marsilia. ${ }^{5}$ It has been impossible to obtain a clear idea of the phloem in longitudinal section, and a careful search has failed to reveal any trace of sieve-plates.

1 1. c., Pl. I, Fig. I represents the stem in Slide Q 104, Cash collection; Pl. XXVI, Fig. 4 of the present account is a photograph of the stem in Slide Q ro3, cut from the same block as Q 104.

$2 \mathrm{Pl}$. XXVII, Fig. I shows the pits in transverse section in the case of a petiole.

${ }^{3}$ Cf. Hick ('96), p. 8 ; the suggestion of spiral elements is very doubtful. Tansley ('08), pp. $\mathrm{I}_{4}$ and I 5 .

4 Tansley ('08), p. I2. Scott ('08), p. 329.

5 Hume, E. M. M. : The Histology of the Sieve-tubes of Pteridium aquilinum, with some notes on Marsilia quadrifolia and Lygodium dichotomum. Ann. of Bot., vol. 26, 1912, p. 573. See pp. 576 and 577 , and Pl. LV, Figs. $3 \mathrm{I}$ and 32 . 
In some cases, sieve-tubes are not present, or the ring may be incomplete ; in these cases the phloem consists of a uniform zone of smaller, narrower cells. $^{1}$ On the whole, the ring of sieve-tubes is less marked in $\beta$ type than in $a$ type stems.

In some well-preserved examples a clearly-defined continuous layer of cells external to the phloem may be considered as representing the pericycle $^{2}$ (Pl. XXVII, Fig. 4); it is, however, frequently impossible to refer the outer tissues of the stele to a definite series (Text-fig. 5).

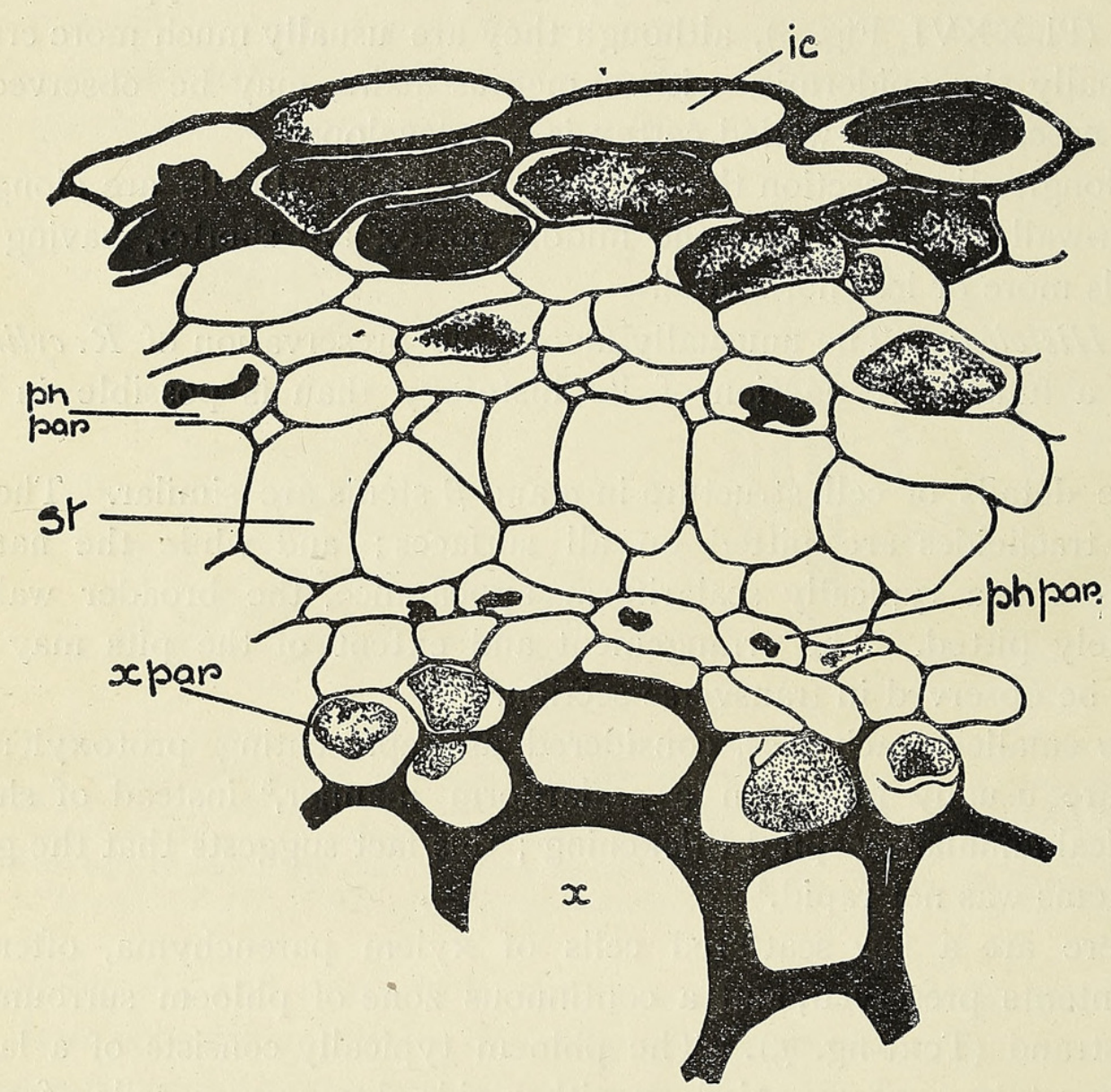

TEXT-FIG. 5. A portion of the stele of an $a$ stem, showing the xylem $(x)$, xylem parenchyma (x.par.), sieve-tubes (st.), phloem parenchyma (ph.par.). The outermost layer of cells $(i c$.$) belongs$ to the inner cortex, having the typical radially-compressed form. Endodermis and pericycle do not constitute distinct layers in this specimen. $\quad \times 400$. (From slide $\mathrm{K} 20$ h, University College, London.)

There is some doubt as to the existence of a true endodermis in stems of $R$. cylindrica. ${ }^{3}$ The stele is usually limited by a somewhat irregular layer of dark-coloured cells, fairly thin-walled, and elongated both tangentially and vertically. This layer, particularly in $a$ stems, sometimes has

1 Hick ('96), p. 7 , notes the apparent lack of differentiation of the phloem cells, but mentions that elements resembling sieve-tubes occur in specimen Q r $0_{4}$.

Tansley ('08), p. I 4, Fig. 4, shows sieve-tubes in specimen K I 4, University College collection.

In Williamson's figure ('78, P1. 24, Fig. 80) there are no sieve-tubes; see p. 350.

2 Hick ('96), p. 7 .

3 Ib., p. 6. 
the appearance of a sharply defined bundle sheath ${ }^{1}$ (Pl. XXVII, Fig. $4, e$ ), the constituent elements of which alternate with those of the pericycle, and also with the cortical cells succeeding them. The distinctness of this darkened layer is very variable, and, particularly in the case of $\beta$ stems, it is sometimes so ill-defined that the stelar tissues appear to grade into those of the cortex without any reliable indication of a limiting layer. The dark colour of these cells seems to be due to the blackening of the contents, which must have been very dense. Sometimes the cells appear uniformly dark, as if the colouring belonged entirely to the walls; in these cases there can have been little or no contraction of the cell contents. At other times the blackened contents have contracted away from the walls, locally or entirely ${ }^{2}$
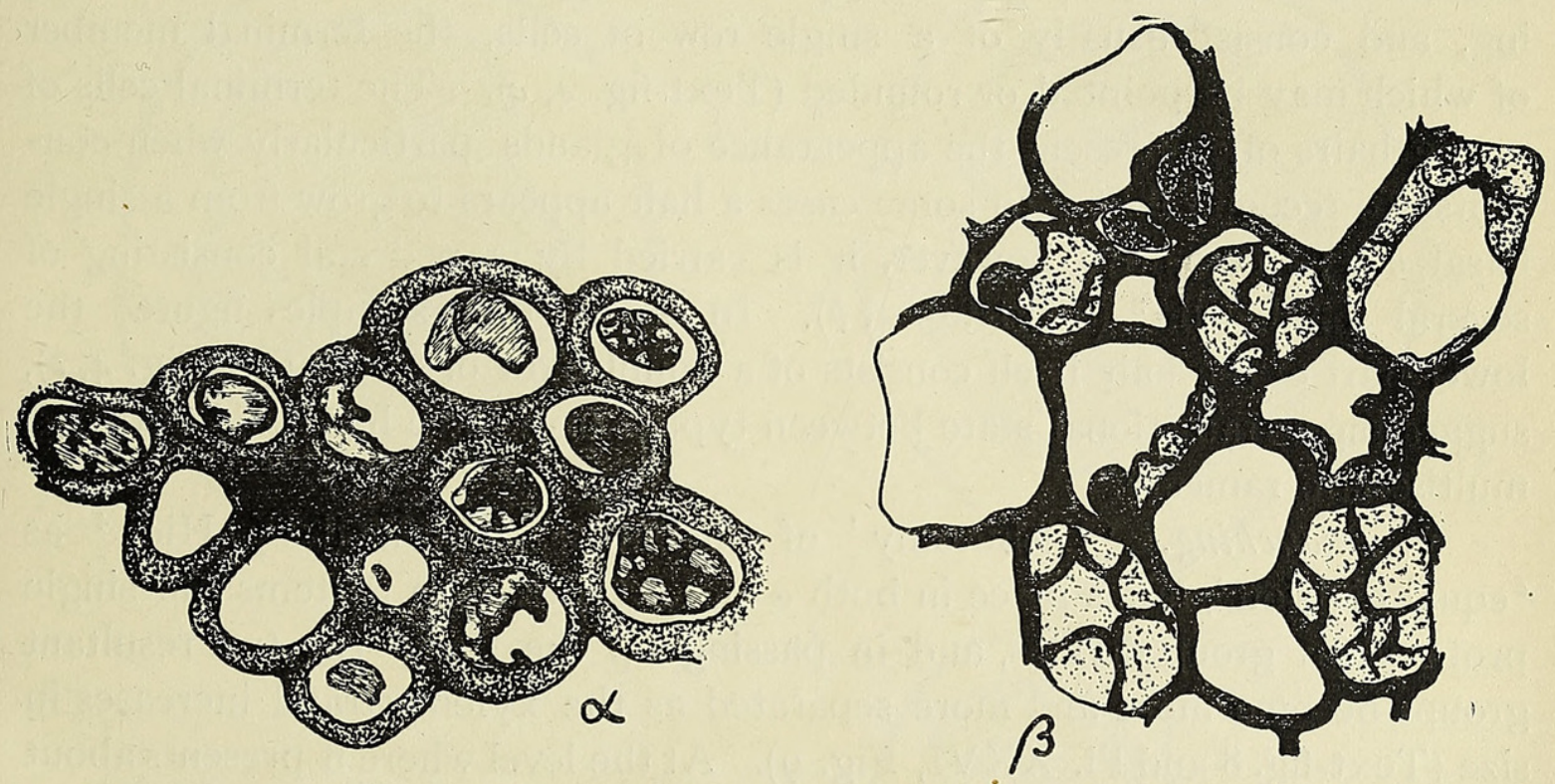

Text-Fig. 6. Portions of the middle cortex of $a$ and $\dot{\beta}$ stems, showing the difference in the thickness of the cell-walls, and the appearances assumed by the contracted cell-contents. $\times 400$. ( $a$, from Q IOI ; $\beta$, from Q I03, Cash collection.)

while in still other cases the cells possess a pitted and reticulate appearance, suggesting uneven adhesion of the contents to the cell-wall, so that subsequent contraction has caused ruptures which now appear as spaces or pits. This appearance may be observed in longitudinal as well as in transverse section $;{ }^{3}$ whether it is natural, or due to a condition of petrifact, ${ }^{4}$ cannot of course be determined.

1 Williamson ('78), p. 350 ; Pl. 24, Fig. 80.

${ }^{2}$ Cf. Scott ('08), p. 329, Fig. I22. In this figure of Botryopteris hirsuta, contraction of the contents may be observed in the darkened cell-layer which ' may be the endodermis'.

Kidston, R.: On a New Species of Dineuron and of Botryopteris from Pettycur, Fife. Trans. Roy. Soc. Edin., vol. $4^{6}$, Pt. II, I909, p. 361. See p. 363: 'the endodermis (of B. antiqua) is clearly defined by its dark contents.'

8 The endodermis of the stem is exactly similar to that of the root, figured in Pl. XXVII, Fig. 3 and Text-figs. $\mathbf{I} 2$ and $\mathrm{I} 3$.

${ }^{4}$ Stopes, M. C. : Petrifactions of the earliest European Angiosperms. Phil. Trans. Roy. Soc., B, vol. 203 , I91 2, p. 75 . See p. 94 . 
Frequently in $a$ stems and occasionally in those of $\beta$ type the contents of the cortical cells are preserved (P1. XXVI, Figs. I and 4, and Text-fig. 6), showing very varied conditions of blackening, granulation, and contraction ; here again the appearances may be due to petrifact, although Hick ${ }^{1}$ is inclined to attach some systematic importance to them. On the whole the cortical cell-contents of $\beta$ stems are less blackened than those of $a$ stems ; representative examples are shown in Text-fig. 6.

With regard to the epidermal cells and hairs, $\mathrm{Hick}^{2}$ has remarked that no contents are recognizable. In cases, however, where the cells are preserved in a growing state, as they are just above a place of branching, delicate, granular and vesicular contents may sometimes be detected. The multicellular hairs, when fully grown, appear to be appressed rather than spreading, and consist usually of a single row of cells, the terminal member of which may be pointed or rounded (Text-fig. $4, c)$. The terminal cells of young hairs often present the appearance of glands, particularly when contents are recognizable. In some cases a hair appears to grow from a single basal cell; frequently, however, it is carried by a pedestal consisting of several small cells ${ }^{3}$ (Text-fig. $4, b$ ). In one of the examples figured the lower part of the hair itself consists of a double row of cells (Text-fig. 4, c), suggesting a transitional state between typical uniseriate hairs and flattened multiseriate ramenta.

v. Branching.- 'Dichotomy' of the stems, described by Hick ${ }^{4}$ as 'equal division', takes place in both $a$ and $\beta$ types. In $\beta$ stems the single protoxylem group divides, and in passing up the stem ${ }^{5}$ the two resultant groups become more and more separated as the xylem strand increases in size (Text-fig. 8 and Pl. XXVI, Fig. 9). At the level where it presents about twice its original dimensions, narrow thin-walled cells occur laterally, and their gradual inward extension separates two equal, or nearly equal, masses of tracheides, each having typically a single central protoxylem group ( $\mathrm{Pl}$. XXVI, Fig. 8 ; Text-fig. 8). ${ }^{6}$ As the strands separate in passing upwards, each becomes surrounded by phloem and endodermis, so that the stem, just below the actual bifurcation, contains two similar steles which are destined for the two branches of the dichotomy (Pl. XXVI, Fig. 8; Text-fig. 8, K 2 I $r$ ).

In the division of typical $a$ stems possessing several protoxylem groups, only one of these is concerned in the production of the branch, the initial strand of which seems to be provided by the division of that group ${ }^{7}$

$$
1 \text { l. c., pp. 4-6. } 2 \text { l. c., pp. } 2 \text { and } 3 .
$$

4. c., p. 9; P1. I, Fig. 2. Scott ('08), p. 333 .

5 See foot-note 4 , p. 533, concerning the acropetal method of description. In the paper quoted, Boodle also justifies the use of words signifying motion of vascular structures, as 'avoiding a lengthy periphrasis' (page 107 , foot-note 2 ).

${ }^{6}$ In Text-fig. 553, the occurrence of two protoxylem groups in one of the branch-steles is not typical ; it appears rather to be a transitory condition than to have any connexion with branching.

7 In the stem figured, the position of the protoxylem groups indicates the division of one of them, lower in the stem, to supply the branch, although none of the series examined shows the actual process. 
Knowledge of Rachiopteris cylindrica, Will.
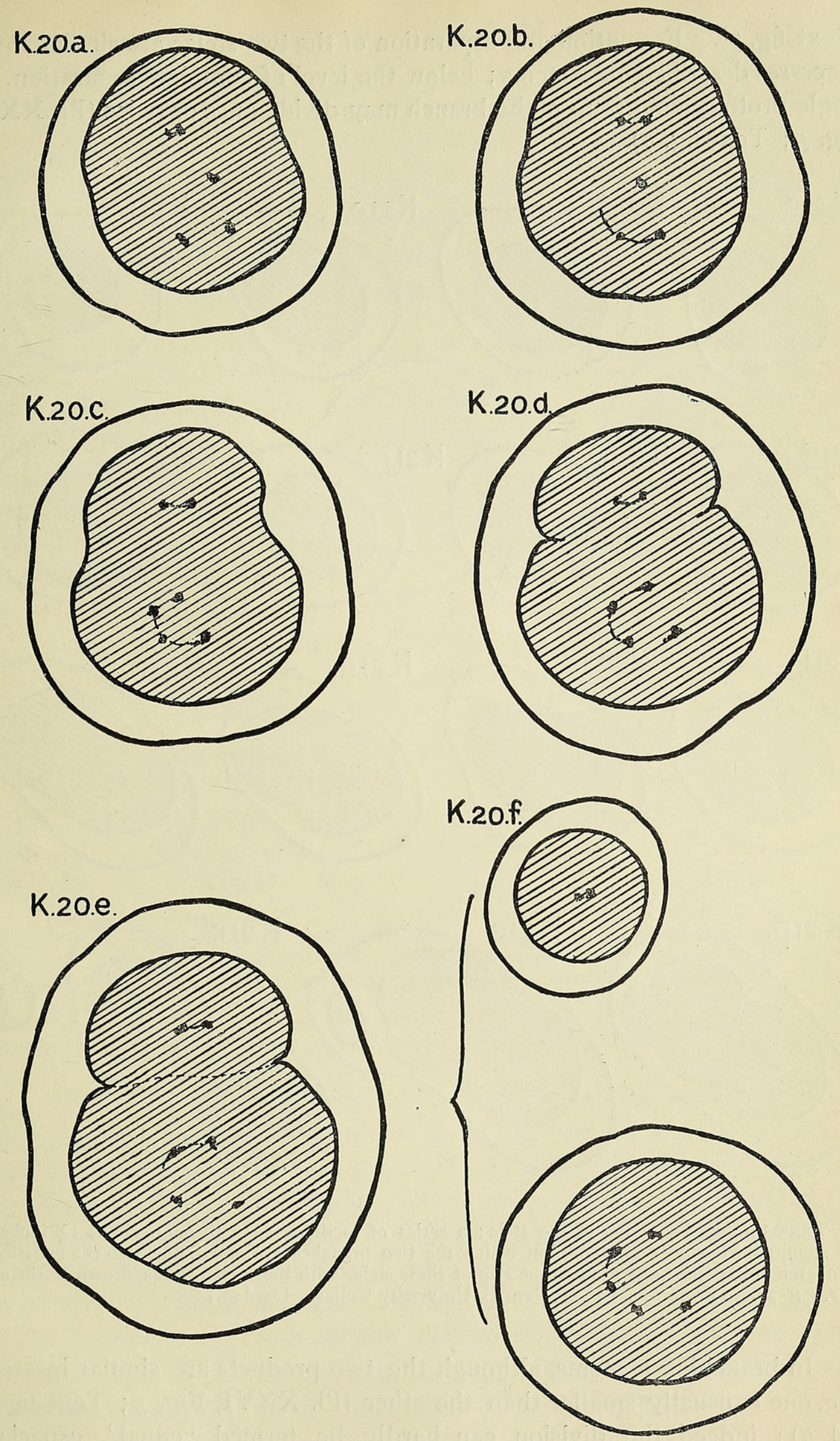

TEXT-FIG. 7. Diagrams of the stele of an a stem, showing 'dichotomy'; the branch stele is considerably smaller than the parent stele. Note the mesarch position of the protoxylem in the large stele, and the occurrence of two strands in the branch even at a low level. $\times 35$. (From series $\mathrm{K}$ 20, University College, London.) 
(Text-fig. 7). Formation and separation of the two steles are similar to the processes described for $\beta$ stems; below the level of complete separation, the single protoxylem group of the branch may divide once or twice (P1. XXVI, Fig. 5 ; Text-fig. 7).
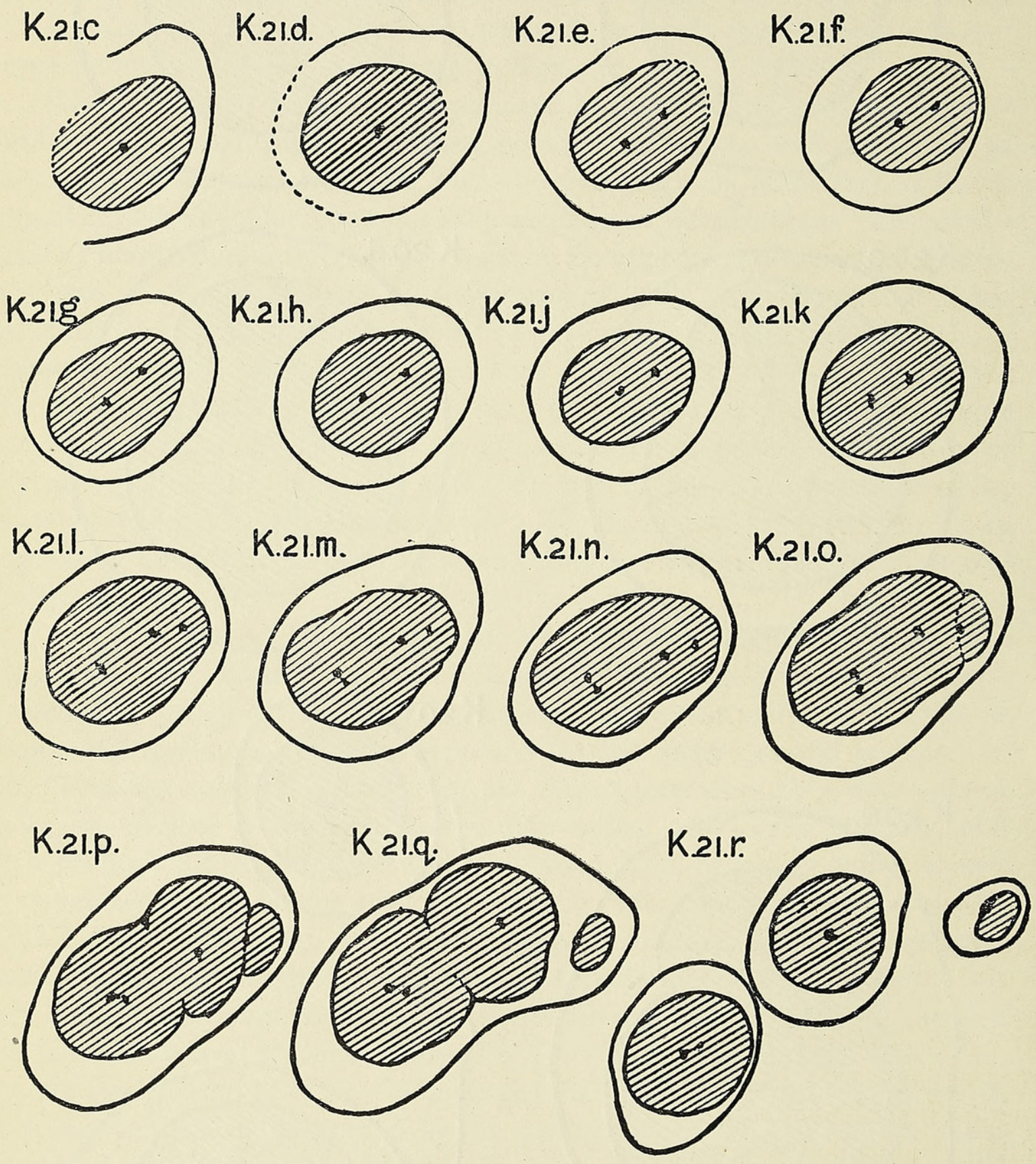

TeXT-FIG. 8. Diagrams of the stele; a series of sections taken through about $\mathbf{I} \frac{1}{2}$ inches of a $\beta$ stem, showing a 'dichotomy' in which the two branches are equal, and also the emission of a monarch foliar-trace. Compare the size of these steles with those of $\alpha$ stems, drawn to the same scale. $\times 35$. (From series K 2 I, stem C, University College, London.)

In branching a stems, although the two products are similar in structure, one is usually smaller than the other (Pl. XXVI, Fig. 5 ; Text-figs. I and 7); indeed the division can hardly be termed 'equal', especially as only one of the several original protoxylem groups participates in branch 
formation. In $\beta$ stems the branches are typically equal in size (Pl. XXVI, Figs. 8 and 9; Text-fig. 8).

\section{Petioles.}

i. Development.-The production of petioles has been described by Hick as a process of unequal division of the stem. ${ }^{1}$ The lowermost stages of their development are exactly similar to those seen in the formation of stem branches; the division of the single, or one of the several, protoxylem

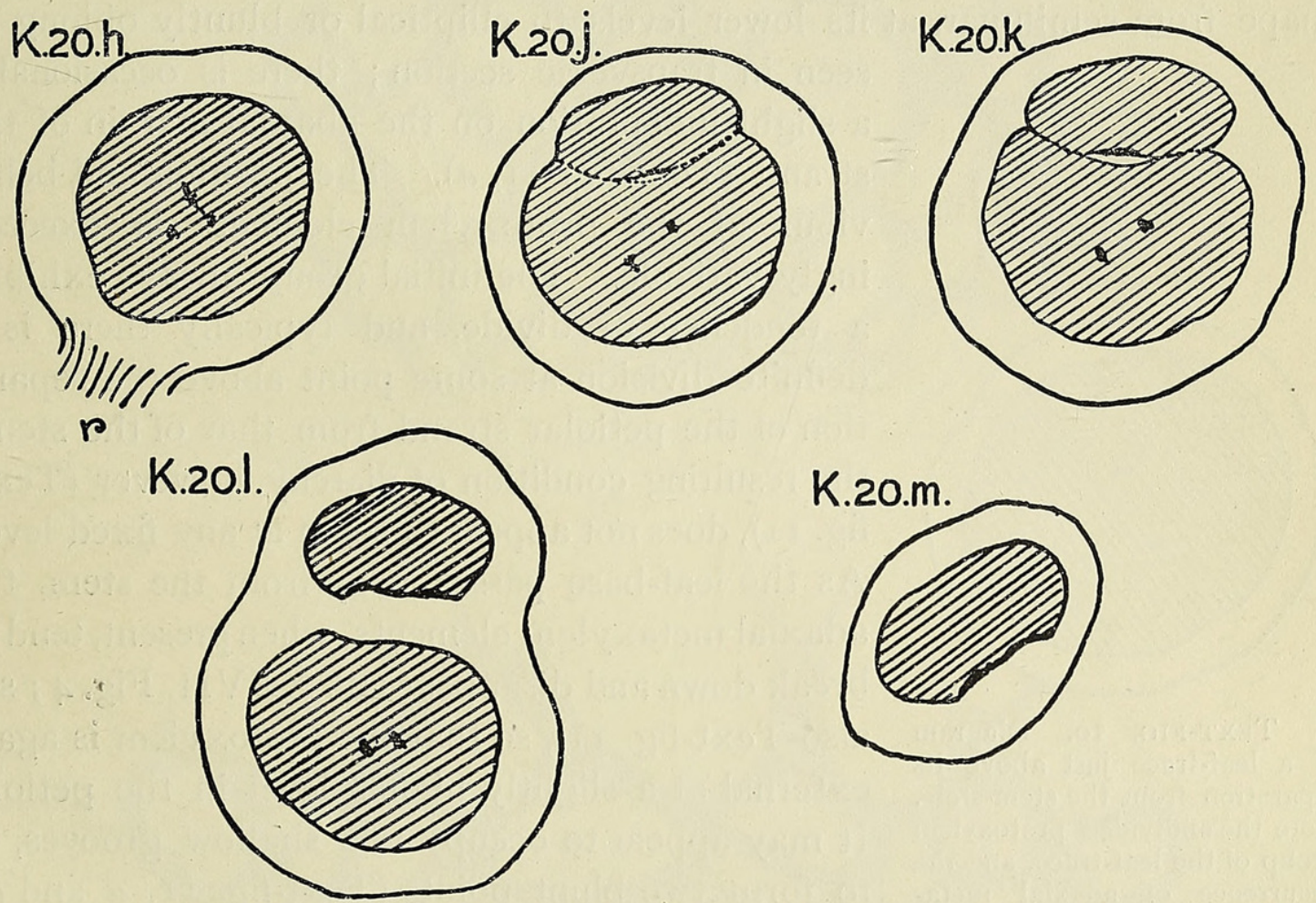

TEXT-FIG. 9. Diagrams of leaf-trace production in the smaller branch of the $a$ stem shown in Text-fig. 7. In $\mathrm{K} 20 h$ indications of root-production are seen at $r ; \mathrm{K} 20 j$ and $\mathrm{K} 20 k$ indicate the appearance of separating cells immediately in front of the protoxylem of the leaf-trace; $\mathrm{K} 20 \mathrm{~m}$ shows the position of the fully-formed petiolar bundle as compared with that of the trace in $\mathrm{K} 20 l$. Note the distribution of the protoxylem along the anterior surface of the leaf-trace, and the absence of adaxial metaxylem. $\times 35$. (From series K 20, University College, London.)

groups (Text-figs. 8 and 9) provides the initial petiolar strand, which in passing upwards becomes separated from the rest by the formation of metaxylem elements (Text-figs. 8 and 9). At a slightly higher level in the stem, thin-walled parenchymatous cells may be observed in front of the petiolar protoxylem (Text-fig. 9; Pl. XXVI, Fig. 6) ; higher still, the lateral extension of these cells completely separates the semi-cylindrical mass of foliar xylem from the stem stele. Always in $\beta$ types, and in some $a$ types also, the protoxylem occurs on the adaxial margin of the petiolar strand (Text-figs. 8 and 9). In other $a$ types the protoxylem, just above the level of trace-separation, is slightly immersed, owing to the occurrence of some

$$
1 \text { 1. c., pp. 9-I I. }
$$


adaxial metaxylem elements (P1. XXVII, Fig. I ; Text-fig. Io). ${ }^{1}$ The endodermis and the remaining stelar tissues close round the xylem, and the leaf-base separates from the stem in the same way as an ordinary branch.

In its outward passage the petiolar bundle may turn slightly away from the stem stele, this deflection being apparently more marked in $a$ than in $\beta$ types (cf. Text-fig. 9 with Text-fig. 8, and Pl. XXVI, Figs. 3 and 7).

ii. a petioles.-These are circular in outline and are smaller than the stems, having an average diameter of $\mathrm{I} .5 \mathrm{~mm}$. They each possess a single xylem strand- $0.45 \mathrm{~mm} . \times 0.3 \mathrm{~mm}$. in average dimension-which varies in shape from semilunar, at its lower levels, to elliptical or bluntly oblong as seen in transverse section; there is occasionally

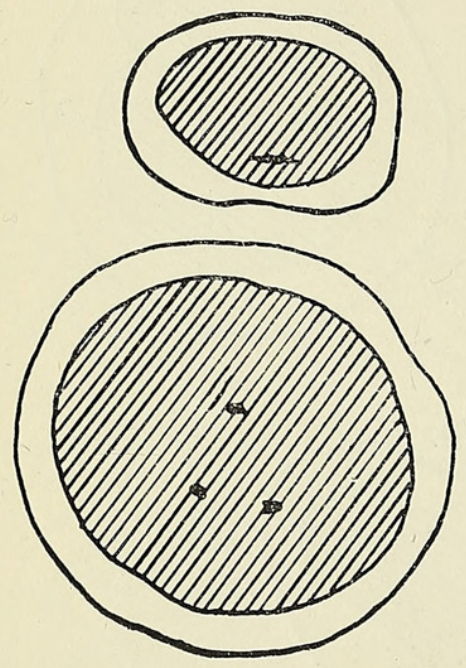

TeXT-FIG. Io. Diagram of a leaf-trace just above its separation from the stem-stele. Note the undivided protoxylem group of the leaf-trace, and the occurrence of adaxial metaxylem. $\times 35 . \quad$ (From slide I 87 , Williamson collect.) a slight indentation on the abaxial margin of the strand (Text-fig. II, $a$ ). The position and behaviour of the protoxylem elements is exceedingly variable. The initial group always exhibits a tendency to divide, and typically there is a definite division at some point above the separation of the petiolar strand from that of the stem; the resulting condition of diarchy, however (Textfig. II), does not appear to set in at any fixed level. As the leaf-base passes away from the stem, the adaxial metaxylem elements, when present, tend to break down and disappear (P1. XXVII, Fig. 4 ; see also Text-fig. I 1 ), so that the protoxylem is again external at a slightly higher level in the petiole. It may appear to occupy two shallow grooves, or to form two blunt points (Text-fig. II, $a$ and $b$ ). In cases where there is no definite division of the protoxylem group, the more or less flattened adaxial margin of the xylem seems to consist almost entirely of small elements ${ }^{2}$ (Text-fig. 9).

The cortex and epidermis of $a$ petioles present the same characters as those of $a$ stems.

iii. $\beta$ petioles. - These also are circular in transverse section, and are

1 Hick ('96), p. 10: 'the smaller segment seems to develop little or no xylem on its inner side.' In Pl. I, Fig. 5, Hick shows an $a$ stem and petiolar bundle from slide Q IOI, Cash collect.; the protoxylem of the leaf-trace appears to be slightly immersed. In Figs. 3 and 4 (from Q 103 and $Q_{102}$ ) are shown two stages in the separation of a $\beta$ petiole, in which the protoxylem is external.

${ }^{2}$ Neither Hick, Scott, nor Seward mentions the number of protoxylem groups in the petiolar bundle of $R$. cylindrica. Hick ('96), p. II, says the petiolar bundle is 'semilunar in form with small elements on the convex side'. According to Scott ('08), p. 333, 'the nearly straight bundle has the protoxylem points all on the same side'. Seward ('10), p. $43^{8}$, describes the leaf-traces as 'semilunar in section, with the protoxylem on the flatter side'. These three accounts indicate the variability of the petiolar vascular system. 
smaller than the parent stems, having a diameter of about $\mathrm{I} \cdot 3 \mathrm{~mm}$. (Pl. XXVI, Fig. 7). The xylem strand, like that of the stem, is much reduced, measuring only about $0.15 \mathrm{~mm} . \times 0.3 \mathrm{~mm}$. Below the level of petiolar separation the trace is usually semilunar in transverse section (Pl. XXVI,
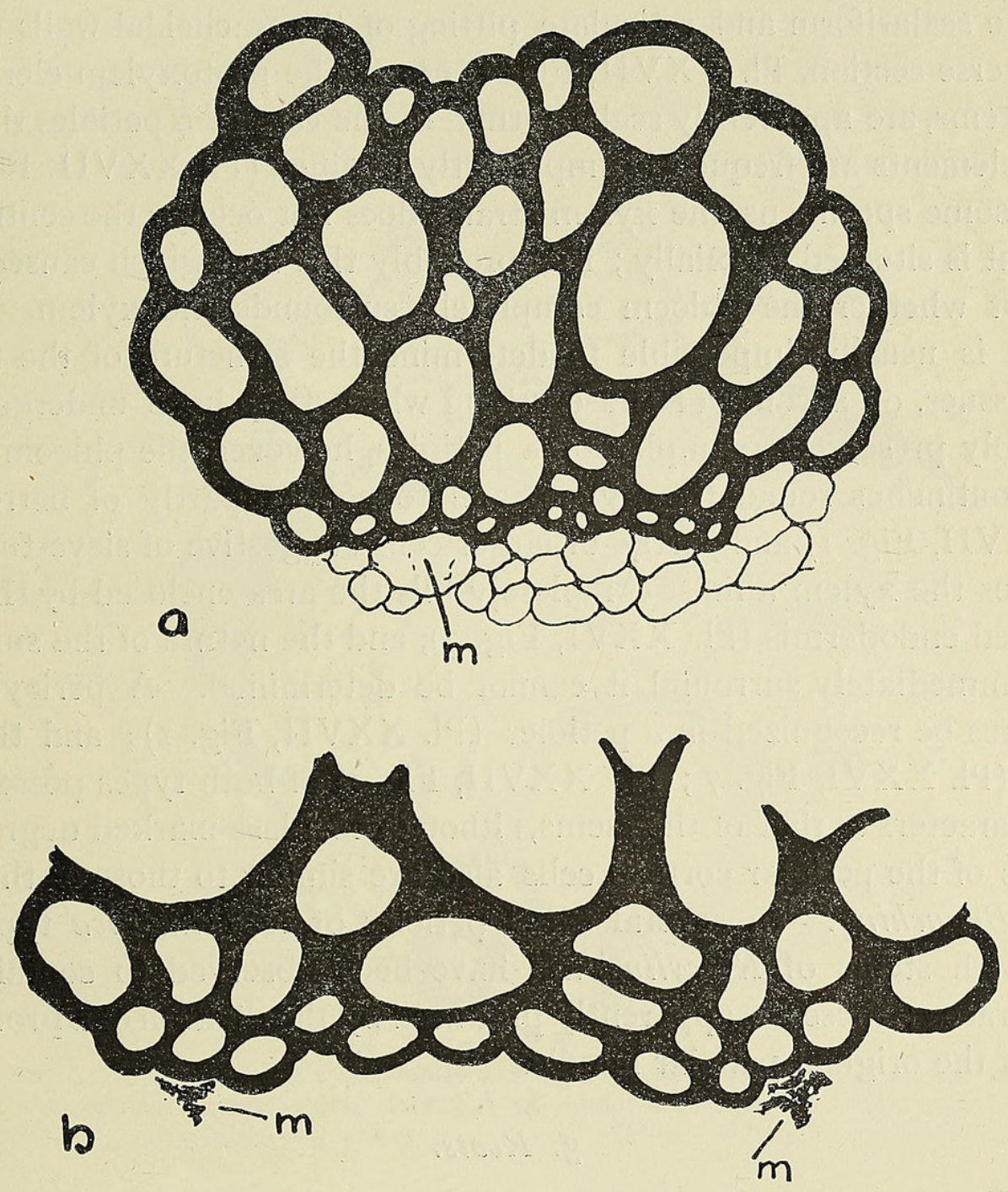

TEXT-FIG. II. $a$, transverse section of a petiolar bundle, showing the adaxial distribution of the smaller elements, which seem to lie in two shallow grooves. At $m$ there is an appearance similar to that figured in Pl. XXVII, Fig. 1, suggesting the breaking down of adaxial metaxylem elements. Note the general shape of the petiolar bundle, and the slight depression of the posterior margin. $\times$ 230. (From slide 1862 , Williamson collect.) $b$, the anterior margin of a similar petiolar bundle, in which the protoxylem seems to be aggregated into two blunt points. At $m$ the cells appear somewhat broken down. $\times 400$. (From slide $\mathrm{r} 861$, Williamson collect.) N.B. It is impossible definitely to refer this petiole to $R$. cylindrica, although its appearance suggests that it belongs to this species.

Fig. 9, lt; Pl. XXVII, Fig. 2); at a somewhat higher level it is bluntly triangular, the protoxylem being concentrated at the apex of the triangle. The monarch condition is maintained in $\beta$ petioles, and no adaxial metaxylem is formed (Pl. XXVI, Figs. 7 and 9; Pl. XXVII, Fig. 2 ; Text-fig. 8), so that the protoxylem is always external.

The cortex of $\beta$ petioles is wide in proportion to the size of the xylem 
strand, and is similar to that of $\beta$ stems. The outer layers are indefinite in structure.

iv. Histology.--In both $a$ and $\beta$ petioles the details of cell structure follow very closely those described for the corresponding stems. No authentic longitudinal sections have been observed, but oblique sections show the scalariform and reticulate pitting of the tracheidal walls (see also a transverse section, Pl. XXVII, Fig. I, pt). The protoxylem elements, as in the stems, are apparently scalariform. In the case of $\beta$ petioles the metaxylem elements are frequently imperfectly lignified (P1. XXVII, Fig. 2).

In some specimens the xylem strand does not occupy the centre of the stele, but is situated abaxially; it is probably this fact which caused Hick ${ }^{1}$ to doubt whether the phloem completely surrounds the xylem. In such cases it is usually impossible to determine the structure of the external stelar tissues, on account of the crushing which they have undergone. In favourably preserved examples of a petioles, however, the phloem appears to be continuous round the xylem, and to consist partly of narrow cells (Pl. XXVII, Fig. I) and partly of larger cells suggestive of sieve-tubes. In $\beta$ petioles the xylem almost completely fills the area enclosed by the rather ill-defined endodermis (P1. XXVI, Fig. 7), and the nature of the small cells which immediately surround it cannot be determined. A pericycle may sometimes be recognized in a petioles (Pl. XXVII, Fig. I); and the endodermis (Pl. XXVI, Fig. 7 ; Pl. XXVII, Fig. I) of both types possesses the same characters as that of the stems, although to a less marked degree. The contents of the petiolar cortical cells also are similar to those of the stems.

v. Branching.-In several cases petioles of $R$. cylindrica type, associated with stems of $R$. cylindrica, have been observed to contain small lateral traces ; these are apparently produced by the division of a protoxylem group of the original petiolar bundle.

\section{Roots.}

i. Development.-Associated with the stems of $R$. cylindrica are numerous small roots, diarch and typically fern-like; similar structures may also be observed in various stages, arising endogenously from both $a$ and $\beta$ stems $^{2}$ (P1. XXVII, Fig. 4 ; Pl. XXVI, Fig. 8). They are scattered at fairly infrequent intervals, typically occurring singly in association with a petiole or branch $^{3}$ (Pl. XXVI, Figs. 3 and 8 ; Text-fig. 9); at times, however, two roots, at different stages, may be seen in the same transverse section of a stem (P1. XXVII, Fig. 4).

1. c., p. II.

2 Cf. Williamson ('78), Pl. 24, Fig. 87; Hick ('96), p. II, and Pl. I, Fig. 2 (from the same specimen in Q 105 , Cash collect., as Pl. XXVI, Fig. 8, of the present account).

3 Cf. Lachmann, J. P. : Contributions à l'histoire naturelle de la racine des Fougères. Ann. Soc. Bot. Lyon, Sér. A, No. I16, I889. See p. 169. The distribution of the roots in $R$. cylindrica is not, according to Lachmann's conclusions, of very primitive type. 
The vascular supply of each root is connected with a group of rather small tracheides occurring at the periphery of the stem xylem ${ }^{1}$; the details of root-formation are, however, difficult to observe.

The passage of the roots through the cortex is variable; it may be horizontal (Pl. XXVI, Fig. 3), or more or less vertical (Pl. XXVI, Fig. 8).

ii. Anatomy and Histology.-The roots of $a$ and $\beta$ types are similar in structure; they vary considerably in size, an average diameter being $0.6 \mathrm{~mm}$.; and they possess a diarch xylem-plate consisting of a few tracheides (P1. XXVII, Fig. 3), all of which appear to be typically scalariform, although here

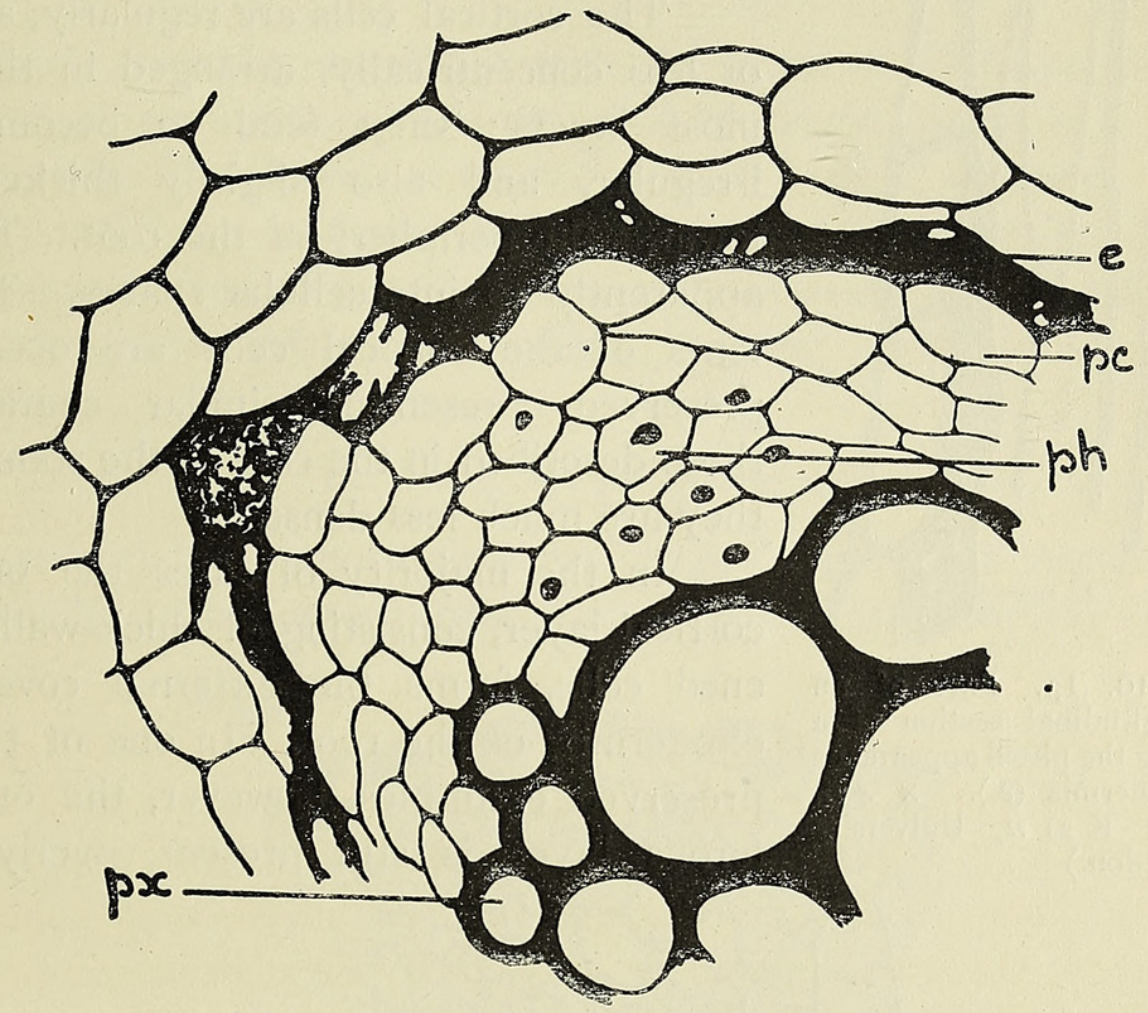

TEXT-FIG. I2. A portion of a well-preserved root, showing in transverse section the phloemcells $(p h$.$) , and the endodermis (e$.$) , the darkened cell-contents of which have here and there a pitted$ appearance; $p x$., protoxylem; $p c_{0}$, pericycle. $\times 400$. (From slide K 2 I $m$, University College, London.)

and there are indications of spiral thickening in the case of the protoxylem elements. The phloem is usually not well preserved; in a few cases, however, it may be recognized as a group of small thin-walled cells on either side of the xylem plate, alternating with its poles (Text-fig. 12). There appears to be a little conjunctive parenchyma, and occasionally a pericycle may be observed underlying the endodermis (Text-fig. 12). The cells of the pericycle are rather irregularly arranged, sometimes alternating with those of the endodermis, at other times being opposite to them. The endodermis is strongly marked, particularly in the older roots (Pl. XXVII, Fig. 3); it has the same characters as that of the stems and petioles, the pitted appearance often being very pronounced (Pl. XXVII, Fig. 3 ; Text-figs. $\mathrm{I}_{2}$ and $\mathrm{I} 3$ ) in both transverse and longitudinal sections

1 Cf. Scott ('08), p. 329; and Seward ('10), p. $43^{8}$. 
of the roots. In the younger examples, the endodermal cell-walls are firm

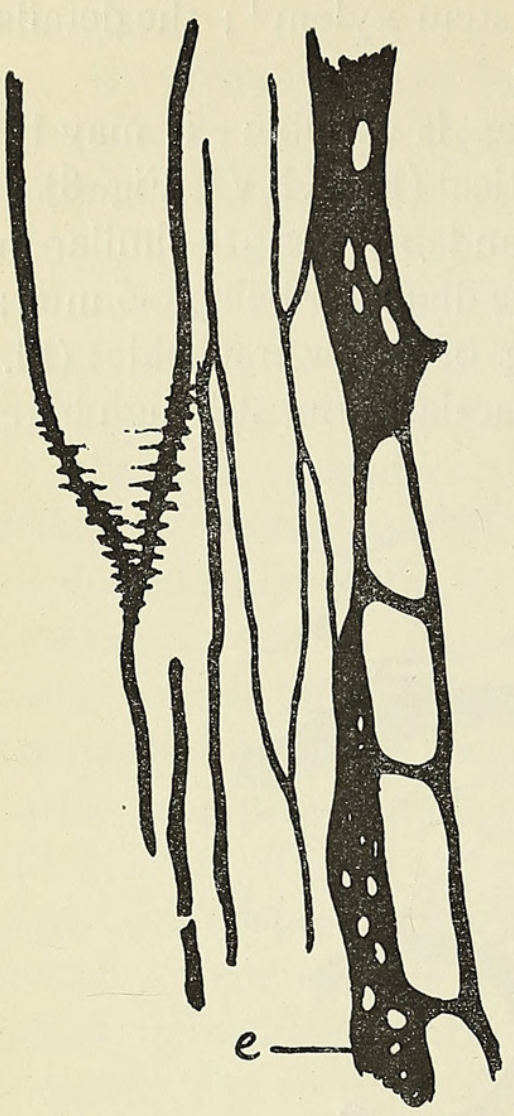

TEXT-FIG. I3. Part of an oblique longitudinal section of a root, showing the pitted appearance of the endodermis (e.). $\times 400$. (From slide $\mathrm{K} 2 \mathrm{I} n$, University College, London.) and dark-coloured, but there is little or no blackening of the contents (Text-fig. I4, a). In one or two instances the cells of the endodermis in the neighbourhood of the xylem poles remain unblackened (Pl.XXVII, Fig. $3, \alpha$ ), as if their contents had been originally less dense. It is possible that these cells may have functioned as 'passage cells'.1

The cortical cells are regularly, and more or less concentrically, arranged in the innermost layers; they tend to become more irregular, and also slightly thicker-walled, towards the periphery of the root. There are apparently no intercellular spaces. The contents of the cortical cells are occasionally preserved, presenting similar characters to those described in the case of the stem, though they are much less dense.

In the majority of cases the outermost cortical layer, consisting of thick-walled darkened cells, forms the external covering, or exodermis, of the root. In one or two wellpreserved examples, however, the outer piliferous layer is still present, overlying the
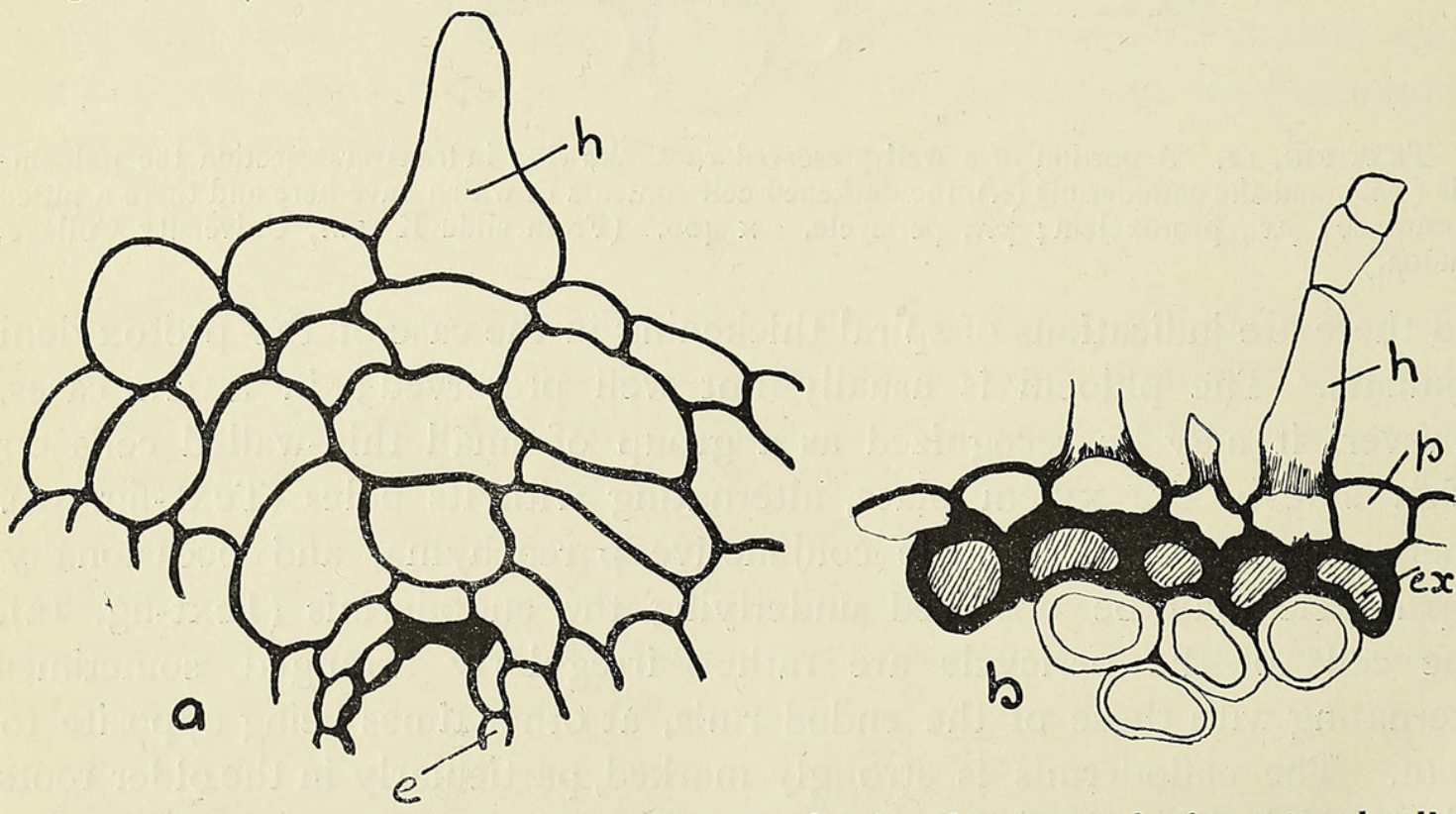

TEXT-FIG. I4. $a$, a portion of a very young root showing the outgrowth of an external cell as a root-hair, $h$. e., endodermis of which most of the cells have unblackened contents. $\times 400$. (From slide $\mathrm{K} 2$ I $l$, University College, London.) $b$, a portion of a root in which the piliferous layer, $p_{0}$, and several root hairs, $h$, are shown ; ex., exodermis. $\quad \times 230$. (From slide Q. I08, Cash collect.)

1 Haberlandt, G.: Physiological Plant Anatomy. English Edition, I914. See pp. 370 and 372. 
darkened outer cells of the cortex. It consists of regular thin-walled elements, which here and there have grown out to form root-hairs (Textfig. $14, b$ ). In another case root-hair production is shown in a very young root, the outer cortical cells of which are still unthickened. ${ }^{1}$

iii. Branching:-Occasionally lateral roots may be seen arising endogenously opposite to the protoxylem groups of the main root; the process, however, is too indistinct for detailed observation.

\section{Organs in Association with $R$. cylindrica.}

In fairly constant association with the stems of Rachiopteris cylindrica are 'axes' of varying sizes, ${ }^{2}$ and detached sporangia similar in type to those associated with Botryopteris ramosa, B. hirsuta, ${ }^{3}$ and B. antiqua. ${ }^{4}$ Although there is usually no evidence of their identity with $R$. cylindrica beyond that of association, this, and their suggestiveness when compared with similar structures referred to allied species, ${ }^{5}$ entitle them to a brief description.

\section{I. 'Axes' of various orders.}

In several cases these detached 'axes' possess a monarch xylemstrand, similar to, but more robust than, the strand of $\beta$ petioles (Text-fig. $I_{5}$ ).

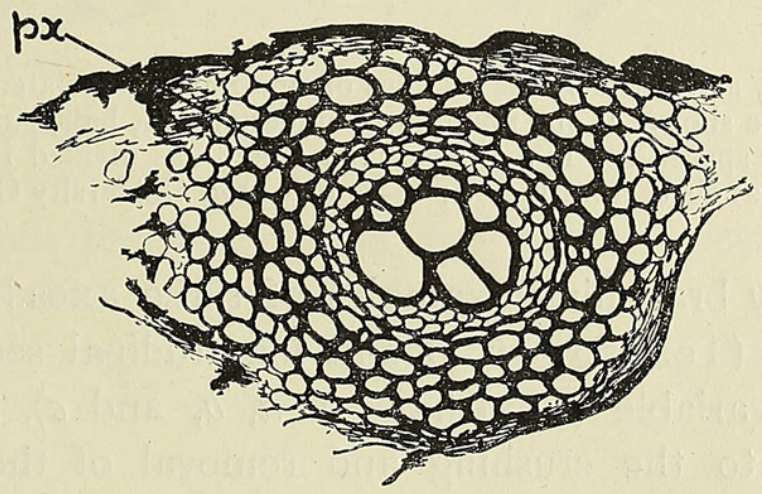

TeXT-FIG. I 5. A monarch 'axis', associated with $R$. cylindrica. $p x_{0}$, protoxylem. $\times 80$. (From slide $\mathrm{K} 2 \mathrm{I} d$, University College, London.)

The similarity of the cortex to that of $a$ organs suggests that these axes are branches of the primary a petioles. ${ }^{6}$

1 So far as the writer is aware, this is the first record of undoubted root-hairs in a Coal Measure plant.

${ }^{2}$ Williamson ('78) mentions (p. 35I), and figures (P1. 24, Figs. 8I-3), axes much smaller than the main stems of $R$. cylindrica, and is inclined to regard them as branches of this plant.

${ }^{3}$ Scott ('08), pp. 332, 333; Fig. I 25.

${ }^{4}$ Scott, D. H. : Sporangia attributed to Botryopteris antiqua, Kidston. Ann. of Bot., vol. 24, I9I0, p. 819. See pp. 819 and 820.

Pelourde, F.: Observations sur quelques végétaux fossiles de l'Autunois. Ann. des Sci. Nat, (Bot.), sér. ix, vol. II, I910, p. 36r. See p. 367 , Fig. 6.

5 See Section V. 2, p. $55^{8}$.

${ }^{6}$ See p. $54^{8}$, 
Numerous examples occur of small axes in which the stele is reduced to a few tracheides surrounded by small thin-walled cells; there is no definite bundle-sheath (Text-fig. I6). The cells of the cortex are large, thin-walled, and irregular in shape. Usually the outermost cells are much crushed, or are entirely unrepresented; in a few instances, however, they may be seen to form a very loose tissue (Text-fig. 16, $b$ ), perhaps comparable with the assimilatory layer in the axes of Stauropteris oldhamia. ${ }^{1}$ The epidermis consists of narrow thin-walled cells which may produce hairs (Text-fig. $16, b$ ).
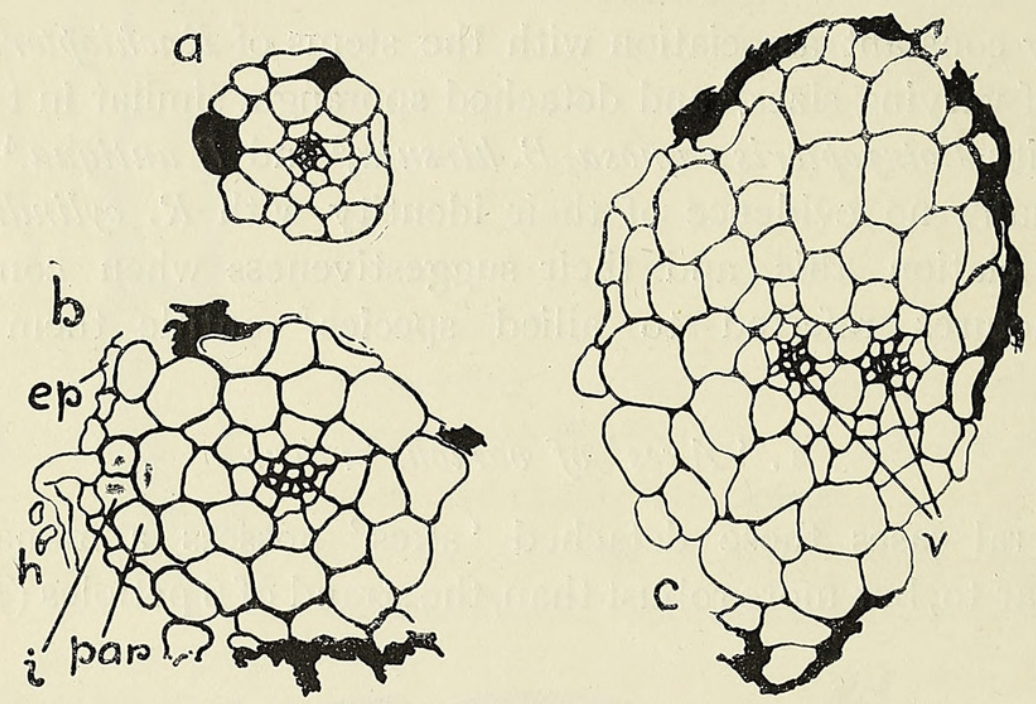

TEXT-FIG. I6. $a, b$, and $c$, transverse sections of small axes associated with $R$. cylindrica. In $b$, the outer cell-layers are shown at one point; ep., epidermis, $h_{.}$, hair, par., parenchymatous cells, separated by intercellular spaces, $i$. In $c$, the vascular strand has divided into two equal groups, $v$. $x$ 80. (a, from slide $\mathrm{K} 2 \mathrm{I} d ; b$, from $\mathrm{K}_{2} \mathrm{I} e ; c$, from $\mathrm{K} 2 \mathrm{I} a$, University College, London.)

Dichotomously branching examples of these axes have been observed in both transverse (Text-fig. I6,c) and longitudinal section. The size of the axes is very variable (Text-fig. I $6, a, b$, and $c$ ), and is difficult to determine, owing to the crushing and removal of the outer cells; the largest seem to be somewhat smaller than the monarch 'axes' described above.

No gradations between these axes and either $a$ or $\beta$ organs of $R$. cylindrica have been observed.

\section{Sporangia.}

The sporangia which occur in association with $R$. cylindrica are rounded or oval in section; the example shown in Text-fig. I7, $a$, measures $325 \mu$ by $400 \mu$. The sporangium wall consists of a single layer of cells which become enlarged locally, forming a pluriseriate annulus (Textfig. I7, a); the inner and lateral walls of the annulus cells are usually somewhat thickened. 
The sporangia contain numerous tetrahedral spores, about $25 \mu$ in diameter ; frequently the triradiate mark may be seen on the spore-coat. In the case of a young sporangium, spore-tetrads, some still enclosed in the mother-cell membrane, are well preserved (Text-fig. 17, b).
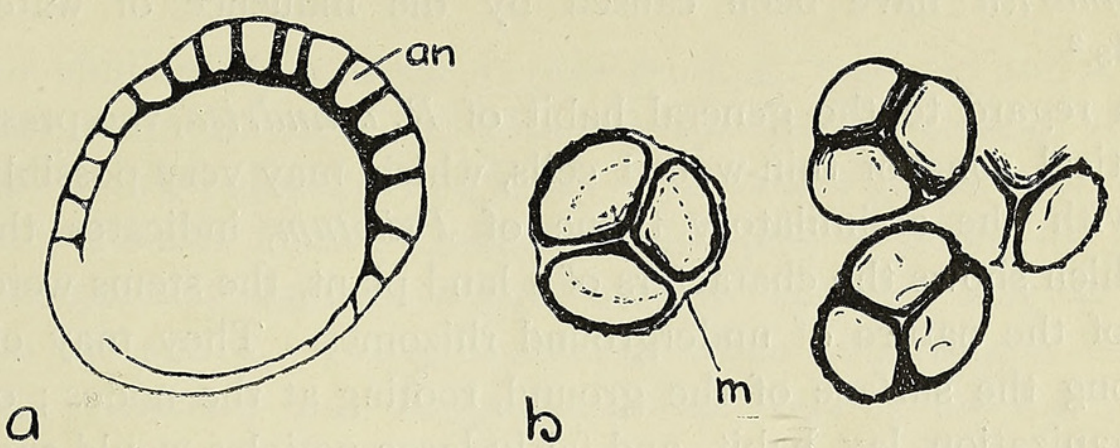

TEXT-FIG. I\%. $a$, a section of a sporangium associated with $R$. cylindrica; $a n$. , 'annulus' cells. $\times$ 8o. (From slide K 2 I $n$, University College, London.) $b$, tetrad groups of spores in a young sporangium associated with $R$, cylindrica. $m$., indications of the mother-cell membrane. In the left-hand group, the dotted line shows the position of the fourth spore, seen at a lower focus. $\times$ 400. (From K 2 I $e$, University College, London.)

\section{General Discussion.}

I. The Significance of the Occurrence of $a$ and $\beta$ types.

The occurrence of the $a$ and $\beta$ types of stems and petioles described above suggests three possibilities, namely, that they represent:

i. different regions of the same plant ;

ii. two distinct though closely allied species;

iii. habitat forms of a single species.

In favour of the first consideration it may be urged that the differences of structure between the two forms are not so great as those existing between different levels of growth in a single plant of Psilotum, ${ }^{1}$ or of Hottonia. ${ }^{2}$ But, although the two forms constantly occur side by side, no transition from one to the other has been observed amongst the numerous specimens examined.

With regard to the second suggestion, the points of similarity in structure and behaviour of $a$ and $\beta$ stems and petioles are too numerous to warrant a multiplication of species names.

The available evidence tends to support the third possibility, indicating that the occurrence of $a$ and $\beta$ types has a bearing upon the 'autecology' of Rachiopteris cylindrica.

The reduction of the xylem strand and its concentration, as exemplified by the presence of only one protoxylem group ; the relatively wide cortex; the production of air-spaces ; and the absence of mechanical tissue-features which characterize both stems and petioles of the $\beta$ type, as compared with

1 Williamson ('78), p. 35 I.

${ }^{2}$ Prankerd, T. L.: On the Structure and Biology of the genus Hottonia. Ann. of Bot., vol. 25 , I9II, P. 253. 
those of the a type-are modifications of structure which find their parallel among water-dwelling forms of recent plants, where they are too well known to require a detailed reference. ${ }^{1}$

It is therefore suggested that the differences between $a$ and $\beta$ types of $R$. cylindrica have been caused by the influence of water upon $\beta$ individuals. $^{2}$

With regard to the general habit of $R$. cylindrica, the presence of an outer cortical zone of thin-walled cells, which may very possibly be comparable with the assimilatory tissue of Psilotum, indicates that in the a type, which shows the characters of a land plant, the stems were exposed, and not of the nature of underground rhizomes. They may either have grown along the surface of the ground, rooting at the nodes; or, as their radial organization, lax habit, and fairly large petioles would suggest, they may have been semi-erect, supporting themselves upon other vegetation.

It must be remembered that any suggestions with regard to the ecological aspects of Coal Measure plants are necessarily very tentative; there is, however, some support for the view that the apparently straggling plants of Rachiopteris cylindrica grew at the edge of swamps or still lagoons. ${ }^{3}$ The evidence drawn from the comparative structure of $a$ and $\beta$ types, and from their constant association with one another, points to the conclusion that the plasticity of the species-which is not necessarily connected with primitiveness ${ }^{4}$-allowed different individuals to exist side by side, some above, and others below, the water level. These individuals respectively constitute the $a$ and $\beta$ types, which may be regarded as habitat forms, or ' ecads' of the species. ${ }^{5}$

\section{The Relationships of $R$. cylindrica.}

Williamson, ${ }^{6}$ in his original description of the organs referred to Rachiopteris cylindrica, mentioned the possibilities that they might be

1 Cf. Schimper, A. F. W. : Pflanzengeographie auf physiologischer Grundlage, I 898.

Land and water forms of Cardamine pratensis (p. 26, Fig. 29) and of Callitriche stagnalis (p. 29, Fig. 32) show the same modifications of structure as $\alpha$ and $\beta$ forms of $R$. cylindrica.

2 The modifications are those caused by fairly still, rather than by strongly-flowing water; $\mathrm{cf}$. Schimper ('98), p. 27.

If these conclusions be tenable, it is interesting to note the presence of hairs in both forms, for as Dombois (Einfluss der geringeren oder grösseren Feuchtigkeit der Standorte der Pflanzen auf deren Behaarung. Inaug.-Diss., Saarbrücken, I887) has shown, these structures tend to be reduced or absent under the influence of moisture. A similar instance to that of $R$. cylindrica, however, is found in Hottonia palustris, where glandular hairs are present on the surface of the aquatic rhizomes and leaves, as well as on the land plants and aerial shoots.

3 Cf. p. $53^{2}$; and foot-note 2 . The excellent preservation of the specimens, and the type of structural modification of $\beta$ specimens, indicate the presence of fairly still water.

4 Cf. the case of Polygonum amphibium.

${ }^{5}$ Clements, F. E. : Research Methods in Ecology. I905. See pp. 148 and 316.

Blackman, F. F., and Tansley, A. G. : Ecology in its physiological and phytotopographical. Aspects. New Phyt., vol. 4, 1905, pp. 199 and 232. See p. 253.

${ }^{6}$ l. c., p. 35 I. 
stems or roots of a Fern, or that they might represent some dwarf Lycopod type; that he personally regarded them as parts of a Fern is indicated by their inclusion in the provisional genus Rachiopteris. ${ }^{1}$ In $1896 \mathrm{Hick}^{2}$ also inclined towards this opinion, which is now accepted without question.

Certain similarities between $R$. cylindrica, $R \cdot$ ramosa, ${ }^{3}$ and $R$. hirsuta ${ }^{4}$ suggest that these Lower Coal Measure species are closely allied; and since Scott ${ }^{5}$ has included the two latter in Renault's genus, Botryopteris ${ }^{6}$ instituted for French Permo-Carboniferous types, of which $B$. forensis is the most completely known-several writers ${ }^{7}$ consider that $R$. cylindrica should also be added. Scott, ${ }^{8}$ however, while admitting a relationship between $R$. cylindrica and Botryopteris spp., retains for the present its original name, and suggests that it may be preferable to institute a new genus for its reception on account of its different habit.

A consideration of structural details indicates that Botryopteris antiqua, a species occurring in the Calciferous Sandstone of Pettycur, ${ }^{9}$ and also, apparently, in the Culm of Esnost, near Autun, ${ }^{10}$ is, of known types, the most nearly allied to Rachiopteris cylindrica, at least so far as the behaviour of the foliar trace ${ }^{11}$ is concerned. There is also evidence that, in this respect, $R$. cylindrica represents a transition stage between $B$. antiqua on the one hand and B. ramosa and B. hirsuta on the other.

According to Gordon ${ }^{12}$ and to Benson, ${ }^{13}$ the petiolar trace in $B$. antiqua

${ }^{1}$ Williamson, W. C. : On the Organization of the Fossil Plants of the Coal Measures. VI. Ferns. Phil. Trans. Roy. Soc., B, vol. 164, 1874, p. 675. See p. 677 .

${ }^{2}$ 1. c., p. I4.

${ }^{3}$ Williamson, W. C. : On the Organization of the Fossil Plants of the Coal Measures. XVIII. Phil. Trans. Roy. Soc., B, vol. 182, I89I, p. 255. See p. 26 I.

4 Williamson, W. C. : On the Organization of the Fossil Plants of the Coal Measures. XV. Phil. Trans. Roy. Soc., B., vol. I80, I889, p. I55. See p. I6r.

${ }^{5}$ Scott, D. H. : On an English Botryopteris. Report of the British Association Meeting at Bristol, I 898 , Section K, p. I050.

Scott, D. H. : Studies in Fossil Botany. First edition, I900, p. 29I.

${ }^{6}$ Renault, B.: Recherches sur les végétaux silicifiés d'Autun et de St.-Étienne. Étude du genre Botryopteris. Ann. des Sci. Nat. (Bot.), sér. vi, t. I, I875, p. 220.

(See also Cours de Botanique Fossile, t. 3, 1883, p. 104; and Bassin Houiller et Permien d'Autun et d'Épinac: Flore Fossile, Pt. II, 1896, p. 33.)

7 Browne ('08), p. 57 ; Seward ('10), pp. 438-40. See also Tansley ('08), p. 14.

8 Scott ('08), pp. 333 and 335 .

9 Kidston ('08).

Benson, M. : New Observations on Botryopteris antiqua, Kidston. Ann. of Bot., vol. 25 , 19 II, p. $1045^{\circ}$

10 Bertrand, C.E., and Cornaille, F. : Les caractéristiques de la trace foliaire botryoptéridienne.

Comptes rendus des Séances de l'Académie des Sciences, t. I50, I9IO, p. Ior9. See p. I022.

Pelourde ('10), p. 364 .

Bertrand, P.: L'étude anatomique des Fougères anciennes, et les problèmes qu'elle soulève. Progressus Rei Botanicae, vol. 4, J912, p. I82. See p. 232.

${ }_{11}$ In a study of relationships the evidence of the foliar trace appears to be of considerable value. See Bertrand ('12).

12 l. c. ('10), p. 400 .

13 1. c., p. 1047. 
has at its lowest levels a single immersed pole near its anterior margin. As the trace passes out, the protoxylem, which either remains single or is duplicated, becomes external, its elements lining one or two shallow adaxial grooves. Sometimes the protoxylem elements appear to be distributed on the anterior margin of the trace. ${ }^{1}$

In the case of $R$. cylindrica the foliar trace possesses at its lowest level a single external pole; a little higher in the trace, the presence of a few adaxial metaxylem elements, in some instances, indicates a relic of an ancestral structure, such as that realized in $B$. antiqua. The protoxylem is, at still higher levels, more or less external in all cases, its behaviour and arrangement in the typical a petioles being very similar to that described for B. antiqua. Sometimes, however, when the protoxylem groups appear to form two minute points, there is a hint of progression towards the condition seen in the tridentate ${ }^{2}$ petioles of Botryopteris ramosa and B. hirsuta. In these species, the petiolar vascular bundle is typically triarch, the protoxylem elements being aggregated into points of very varying prominence in different specimens. The three groups result from the division of the single pole of the leaf-trace.

Miss Benson ${ }^{3}$ explains the increase in the number of poles from one to three in the evolution of the botryopteridean trace, as being due to the arrest of branching at an early stage ; this increase seems to be accompanied by the gradual protrusion of the protoxylem groups. ${ }^{4}$ In accordance with this view, it is suggested that $R$. cylindrica represents an intermediate, though not very advanced, stage in the series, for while protrusion of the protoxylem is indicated in some specimens, its arrangement is usually more reminiscent of that in $B$. antiqua.

According to Paul Bertrand's earlier work, ${ }^{5}$ the botryopteridean trace, as represented by that of $B$. forensis, may be derived from the reduction of an ancestral bipolar form. As Scott ${ }^{6}$ notes, this author does not take into account the trace in related and older types; while Miss Benson ${ }^{7}$ shows that if Bertrand's view be accepted, the early occurrence of a monarch trace, in $B$. antiqua, indicates a process of simplification within the series-an indication with which the triarch petiolar bundles of later species are not in harmony. It seems more reasonable to regard at least $B$. antiqua,

${ }^{1}$ Killston ('08), p. $3^{6} 3$; Pelourde ('10), p. $3^{6} 6$, Fig. 2.

2 Felix, J. : Untersuchungen über den inneren Bau westfälischer Carbonpflanzen. Abhandl. Kön. Preuss. geol. Landesanst., Bd. 7, I886, p. [153]. See p. [164], and Taf. I, Fig. 2.

Scott ('98), p. I05०.

In $\beta$ petioles, the single pole typically forms a distinct point.

3 1. c., p. I05I.

4 ibid., Text-fig. 2, p. I051.

5 1. c. ('09), p. 238.

${ }^{6}$ Scott, D. H. : Review of Dr. P. Bertrand's work, Études sur la fronde des Zygoptéridées (Lille, I909). New Phyt., vol. 8, I909, p. 266. See p. 27 I.

7. 1. c., p. I053. See also Bertrand's general agreement with Miss Benson's criticism, ('12), p. 233 . 
R. cylindrica, and B. ramosa and hirsuta as forming a series in which the foliar traces show progression from a simple structure in the oldest species to a more complex development in the later species; for, as Bertrand ${ }^{1}$ now admits, the simple trace of $B$. antiqua may readily be derived from a basal, generalized form - $a$ rounded or oval mass of wood having a single central pole-by a slight anterior displacement of the protoxylem. According to this view, the foliar traces of the Botryopterideae, Osmundaceae, Psaronieae, and Zygopterideae may be referred to a common ancestral type. ${ }^{2}$

The branching of the petiolar bundles in B. antiqua, ${ }^{3}$ B. ramosa, and $B$. hirsuta is lateral, and there are indications that it is of the same type in $R$. cylindrica. The secondary traces are usually smaller than the parent strand, and their protoxylem is apparently provided by the division of one of the petiolar groups. In the case of the triarch petioles of $B$. ramosa and $B$. hirsuta, the central protoxylem group is not concerned in the production of branch traces.

With regard to stem structure, $R$. cylindrica is essentially very similar to the three British species of Botryopteris. In each case the stem is protostelic, the differences depending chiefly upon the varying position of the protoxylem groups. It is not, however, possible to trace an evolutionary series like that exhibited by the foliar bundles.

In $B$. antiqua the position of the protoxylem is variable and indefinite ${ }^{4}$; many scattered peripheral elements occur in the root-bearing zone of the stem. These are no doubt comparable with the small elements giving rise to roots in the other species. In the leaf-bearing zone, there are only one or two mesarch groups; the same number occurs in B. ramosa, where they are, however, placed towards the centre of the xylem strand; B. hirsuta apparently presents a similar condition. It has been shown that the vascular strand of $R$. cylindrica may possess a single endarch group, or from two to five groups in a mesarch position, the chief distinction between this and the other species consisting in the slight and varying differentiation of the internal xylem in typical specimens. Whether this differentiation is indicative of a higher or lower development of the vascular strand is open to much discussion; its theoretical significance will be discussed in the next section. ${ }^{5}$

The similarity in general stem structure in these species extends to the pitting of the tracheides, which is of scalariform and reticulate type. Scalariform pitting seems to be predominant in $B$. antiqua, and reticulate pitting in $B$. ramosa and $B$. hirsuta; whether there is any significance in

1 1. c. ('12), p. 233 .

2 Bertrand ('12), p. 299.

Kidston, R., and Gwynne-Vaughan, D. T. : On the Fossil Osmundaceae. Pt. I. Trans. Roy. Soc. Edin., vol. 45, Pt. III, 1907, p. 759. See pp. 777 and 778 .

Gordon ('11), p. 733 .

${ }^{3}$ Benson ('11), p. I048.

1 ibid., p. I046.

${ }^{5} \mathrm{p} .5^{6} \mathrm{I}$. 
this fact ${ }^{1}$ is uncertain, for in $R$. cylindrica it is evident that the distribution of the two types depends upon the width of the tracheide walls. ${ }^{2}$

There is thus considerable agreement in the organization of the four species, and in view of this fact it is interesting to note that the associated sporangia in each case are of similar type.

It is inadvisable to draw any conclusions from the apparent absence of a leaf of ordinary Fern type within this group. In $B$. ramosa there are indications that the frond was much dissected, as in Stauropteris and members of the Zygopterideae; while the presence of small axes associated with $R$. cylindrica suggests incomplete foliar development in this species also-a suggestion which is supported by the probable assimilatory nature of the outer cortex of the stem and petiole. Smaller axes, again, occur in association with the petioles of $B$. antiqua, but it is as yet impossible to say what the exact condition of foliar development may have been in these plants; and in any case, similarities or differences may have been due to the influences of environment rather than to degree of relationship.

The four species differ to a certain extent in habit. $B$. antiqua is considered by Kidston ${ }^{3}$ to have been a scrambling plant requiring support for its large leaves, some of which were accompanied by sheathing aphlebiae. ${ }^{4}$ Seward ${ }^{5}$ suggests that the slender plants of $B$. ramosa, with their much branched leaves, were epiphytic in habit; while $B$. hirsuta seems to have been similar, though with larger and less crowded leaves. There are indications that $R$. cylindrica was an 'amphibious' plant; its dichotomously branched stems were of lax habit and bore few leaves, the inadequacy of which is suggested by the development of apparent cauline assimilatory tissue.

These differences, however, are not greater than are to be found amongst closely-related types-even within a single genus-at the present day. The diversity of habit, and of habitat, amongst the species of Polygonum may be mentioned as an example.

It may be concluded that $B$. antiqua, $R$. cylindrica, $B$. ramosa, and $B$. hirsuta form a group of closely-related species, showing, at least in the behaviour of the foliar trace, a gradual transition from a simple to a more complex structure.

Botryopteris forensis, as representative of the French Permo-Carboniferous species, seems to stand a little apart from the group of older British species.

1 Stopes, M. C. : A New Fern from the Coal Measures: Tubicaulis Sutcliffii, spec. nov. Mem. and Proc. Manchester Lit. and Phil. Soc., vol. 50, Pt. III, I906. See p. 24.

Gordon ('10), p. 400 ; Seward ('10), p. 436.

${ }^{2}$ Cf. Scott ('08), p. $3^{26 .}$

3 1. c., p. 364 .

4 Benson ('11), pp. 1048 and I049; Text-figs. $1 ~ a$ and $1 b$.

5 l. c., p. 44I. 
With regard to the foliar trace, the exact details of its emission have not been described, but it is evident that the fully-formed petiolar bundle is much more complicated than that of the four species just considered. It is, in general shape, like an $\omega$, the arms of which point towards the centre of the stem, and it has been compared with the tridentate bundles of $B$. ramosa and $B$. hirsuta, where the three projections are much smaller.

In $B$. forensis the foliar bundle is described as consisting of an essential or 'principal' segment-the centre arm of the $\omega$; and two accessory or 'receptive' segments-the two lateral arms. ${ }^{1}$ These latter are believed by Bertrand to be secondary developments to compensate for the extreme reduction of the essential part of the trace and to provide the metaxylem of the branch-traces. The principal segment was originally considered to have been derived from a primitive bipolar trace, in which extreme contraction of the anterior surface had taken place ${ }^{2}$; more recently Bertrand ${ }^{3}$ has admitted that the Botryopteridean trace may have been derived directly from a unipolar ancestor. In either case, however, its reduction was apparently such as to require the development of the receptive parts, and these were, according to Bertrand ${ }^{4}$ already present in the older types B. antiqua and B. ramosa, although in a condensed state, forming one mass with the principal segment.

Branching phenomena certainly demonstrate that the centre arm of the $\omega$ must be regarded as the essential segment. At the base of the petiole, it possesses, at its free extremity, two lateral, slightly-sunken poles, ${ }^{5}$ which by their division provide the protoxylem strands of the branch traces.

The central arm of the $\omega$ is thus, at this stage, a much more elaborate structure than the central point of a tridentate petiolar bundle. Higher in the leaf, however, it possesses only a single terminal protoxylem group, and according to Bertrand and Cornaille, ${ }^{6}$ further reduction of the trace produces tridentate bundles, similar to those of $B$. hirsuta, which, as already mentioned, are also held to include principal and receptive segments in a condensed state. The ultimate traces of B. forensis are monarch, but these cannot be compared with the monarch phase of the earlier species, for they are said to consist only of the two receptive segments, the principal segment not being represented at this high level; the monarch phase of the British species, on the other hand, must include the principal segment. ${ }^{7}$

The significance of these facts is doubtful ; for if B. forensis, B. ramosa, and $B$. hirsuta belong to the same series, and if the simpler tridendate traces are representative of a reduction phase, then the geologically older and $23 \mathrm{I}$.

1 Bertrand ('09), p. $23^{8}$; Bertrand and Cornaille ('10), p. Ior9; Bertrand ('12), pp. 230

${ }^{2}$ Bertrand ('09), p. 238 .

5 Bertrand ('12), p. 23 I, Fig. 26.
3 1. c. ('12), p. 233 .

6 1. c., p, IO22.
4 1. c. ('12), p. 232 。

7 ibid., p. 1022. 
species of the genus realize this phase at a lower level of petiolar development-that is, at the base of the petiole instead of in an ultimate branch. They may thus be regarded as further from the ancestral type in this respect than $B$. forensis; also their simplicity cannot be due to primitiveness.

Again, since the traces of $B$. antiqua and $R$. cylindrica are clearly simpler members of the same series as the tridentate forms, ${ }^{1}$ it may be argued that further simplicity is due to further reduction; if this be so, the oldest species of the series must possess the most reduced trace.

It has been shown, however, that the foliar traces of $B$. antiqua, $R$. cylindrica, and $B$. ramosa and hirsuta form a connected progressive series which may be derived from an ancestral type of trace; and, in the absence of advancing intermediate stages connecting the simple tridentate traces with that of $B$. forensis, it may be advisable to consider this species as being somewhat removed from the earlier types.

In stem structure also, $B$. forensis differs from the British types, for the solid protostele is definitely exarch. ${ }^{2}$

The plant is known to have possessed a leaf with thick, dichotomously branched veins and small fleshy pinnules-the only example of an ordinary leaf yet known amongst the species of Botryopteris.

The sporangia, again, seem to isolate $B$. forensis from the British species. They have been described as possessing a two-layered wall, ${ }^{3}$ the inner layer being often distinguishable only as a thin membrane. According to Oliver, ${ }^{4}$ some specimens referred to the provisional genus Tracheotheca ${ }^{5}$ may perhaps have belonged to $B$. forensis; their walls are lined with a delicate tracheal layer unlike anything observed in the earlier species. Its presence, of course, may be merely the result of environmental influences. ${ }^{6}$

It is concluded that Rachiopteris cylindrica is allied to Botryopteris antiqua, B. ramosa, and B. hirsuta, the four species forming a group, with which $B$. forensis is not very closely related. This conclusion suggests that the desirability of including Rachiopteris cylindrica in the genus Botryopteris must be determined by the desirability of retaining there its three related types.

\section{Theoretical Considerations.}

Rachiopteris cylindrica presents several points of theoretical interest, two of which will be briefly discussed.

1 Kidston ('08), p. 364 .

${ }^{3}$ Renault ('96), pp. 53 and 54.

${ }^{4}$ Oliver, F. W. : A Vascular Sporangium. New Phyt., vol. I, I902, p. 60.

${ }^{5}$ Oliver, F. W.; On the Structure and Affinities of Stephanospermum, Brongniart, a Genus of Fossil Gymnosperm Seeds. Trans. Linn. Soc., Bot., vol. 6, I904, p. 36I. See foot-note, p. 395.

${ }^{6}$ Seward ('10), p. 443 . 


\section{i. The Primitiveness of the Stelar Condition.}

R. cylindrica has been described by Tansley ${ }^{1}$ as possessing an endarch protostele, and as being therefore primitive in this respect. But it has been shown that the a forms, at least, are not in the majority of cases typically endarch ; they rather tend towards mesarchy, ${ }^{2}$ and even, in some specimens, towards a differentiation of the xylem into inner and outer zones.

On the assumption of Tansley's theory - and there is much in favour of the primitiveness of endarchy amongst the ancestors of vascular plants as a whole ${ }^{3}$ - the 'mesarch' $a$ stems are to be considered as having made a slight advance upon the primitive condition, particularly in those cases where there is differentiation of the internal wood. ${ }^{4}$ True endarchy is met with in some branches of $a$ stems and in the $\beta$ stems; its occurrence in R. cylindrica, however, cannot be considered as having any bearing upon the primitiveness of the vascular structure ; for in a stem branches it represents a derived and reduced condition, due probably to decrease of vigour, and in $\beta$ types, if the argument of concentration under the influence of a water habitat be tenable, the same condition is again due to reduction.

From a study of the Fossil Osmundaceae, Kidston and GwynneVaughan ${ }^{5}$ conclude that the ancestral form of this group must have possessed an exarch protostele ; and Lady Isabel Browne ${ }^{6}$ is of the opinion that exarchy represents the primitive condition of the Pteridophyta as a whole. Bertrand, ${ }^{7}$ however, considers that if the protostele is to be regarded as the original stelar type, its protoxylem groups were most likely slightly immersed.

According to any of the above views, it is evident that typical specimens of Rachiopteris cylindrica-apart from the cases where endarchy occurs as a state of reduction-show some divergence from the ancestral structure.

A consideration of Bertrand's theory of the 'étoile libéro-ligneuse', ${ }^{8}$ or 'asterostele', suggests that such forms as the mesarch $a$ stems of $R$. cylindrica may be more primitive than truly endarch forms, since they may represent a stage in the condensation of an ancestral rayed structure like that of Cladoxylon; the endarch condition itself, according to Bertrand, denotes a very advanced state of condensation. It has certainly been shown that, in a stem branches, endarchy results from the condensation of a dispersed condition of the protoxylem groups; as mentioned above, this may be due to a decrease of vigour. In $\beta$ stems, endarchy is considered to be due to the action of environment, causing concentration of the vascular tissues. Since, in these cases, the occurrence of endarchy may be explained on physiological grounds, it can hardly be accorded any phylogenetic

\footnotetext{
1 1. c., pp. 14 and 15.

4 Gordon ('10), p. 400.

2 Browne ('08), p. 57.

5 1. c., p. 777.

7 1. c., ('12), p. 263.

8 Bertrand ('12), pp. 249-6I.

3 Tansley ('08), p. I5.

6 1. c., p. $5^{8}$.
} 
significance. It is only possible to say that if the theory of the asterostele be tenable, typical examples of $R$. cylindrica represent a stage much in advance of the primitive condition.

According to Lignier, ${ }^{1}$ the primitive vascular system was a solid exarch xylem mass; during the course of evolution this underwent a process of dissection and of subsequent concentration which, to a certain extent, recalls the behaviour of Bertrand's asterostele. Lignier's theory, again, would place $R$. cylindrica far from the original type.

It is therefore impossible to say with certainty whether the stele of $R$. cylindrica is more or less highly organized than those of related species ; it is, however, reasonable to conclude that typical examples are not primitive according to any of the theories mentioned above.

\section{ii. The Homology of the Leaf.}

A comparison of the methods of stem-branching and leaf-production in $R$. cylindrica provides evidence in favour of the view, suggested by Bower ${ }^{2}$ in $I 884$, that stem and leaf are homologous branches of a primitively undifferentiated and dichotomous system. This view is now the basis of the hypothesis set forth by Potonié, ${ }^{3}$ Hallier, ${ }^{4}$ Lignier, ${ }^{5}$ Tansley, ${ }^{6}$ and Bertrand ${ }^{7}$; according to Tansley it 'carries with it the necessity of looking upon the branching away of the leaf-trace from the vascular system of the stem as in origin a separation of the vascular strand into branches of equivalent morphological status' ${ }^{8}$

Stem-branching and leaf-production have been described in $R$. cylindrica, and it is evident that the two processes are essentially the same in origin. In branching, however, the completion of both branch steles is ensured by the formation of metaxylem elements below the actual level of their separation (see Pl. XXVI, Figs. 5 and 9; Text-fig.7); in leaf-production, on the other hand, only the stem stele is completed in this way, for at the

1 Lignier, O.: Organisation progressive du parcours des faisceaux libéro-ligneux dans le mériphyte des Phyllinées. Bull. Soc. Bot. de France, t. $5^{8}$, I9I I, p. 29.

Lignier, O.: Essai sur les transformations de la stèle primitive dans l'embranchement des Phyllinées. Bull. Soc. Bot. de France, t. $5^{8}$, I9I I, p. [87].

2 Bower, F. O.: On the Comparative Morphology of the Leaf in the Vascular Cryptogams and Gymnosperms. Phil. Trans. Roy. Soc., B, vol. I 75, I 884, p. 565. See p. 605. (Bower has now abandoned this theory.)

${ }^{3}$ Potonié, H. : Ein Blick in die Geschichte der botanischen Morphologie und der Pericanlomtheorie. 1903, p. 33 .

See also Lehrbuch der Pflanzenpalaeontologie, 1899, pp. 156-9; and other references.

${ }^{4}$ Hallier, H. : Beiträge zur Morphogenie der Sporophylle und des Trophophylls in Beziehung zur Phylogenie der Kormophyten. Jahrb. der Hamburgischen wissenschaftlichen Anstalten, I9, I90I (published 1902). See p. 45 and p. I04.

5 Lignier, O.: Essai sur l'évolution morphologique du Règne végétal. Bull. Soc. Linn。 de Normandie, sér. 6, vol. 3, 1908-9, p. 35. Reprinted, I9I I. See other references also.

${ }^{6}$ l. c., p. I of reprint. $\quad 7$ l. c. ('09), pp. $260,26 \mathrm{I}$; ('12), p. 278.

${ }^{8}$ 1. c., p. 3 of reprint (cf. New. Phyt., vol. 6, 1907, p. 26). 
place of separation the leaf-trace does not appear to possess any adaxial metaxylem (Pl. XXVI, Figs. 6 and 9; Text-figs. 8 and 9). A few elements may be developed higher in the petiolar trace, but at a slightly higher level still they tend to disappear again; their formation may be regarded as indicating an earlier condition similar to that seen in Botryopteris antiqua, in which some adaxial metaxylem is present at the level where the trace separates from the stem stele, and which is therefore still more suggestive of modified stem-branching.

This view of the origin of the leaf is further supported by the similar behaviour of the protoxylem in branching and in leaf formation. In $a$ types, the protoxylem group of both branch- and leaf-traces divides more or less definitely; in $\beta$ types, no division normally takes place in either instance.

\section{Summary.}

\section{Distribution and Horizon, p. $53^{2}$.}

Rachiopteris cylindrica appears to be restricted to the HalifaxHuddersfield area, where it occurs in the nodules of the Halifax Hard Bed of Lower Coal Measure Age.

\section{Description, p. 532.}

The stems and their corresponding petioles may be referred to two types, described as $\alpha$ and $\beta$ respectively.

i. $a$ stems are characterized by a well-developed xylem strand exhibiting a marked tendency towards mesarch structure, with differentiation of the central elements; the inner and middle cortical areas have fairly thick-walled cells, while the outer cortex is composed of a few layers of thin-walled cells, suggestive of an assimilatory tissue. a petioles also have well-developed xylem strands, frequently with distinct diarch structure; their cortex is like that of $a$ stems.

ii. $\beta$ stems possess only a small monarch, centrarch xylem strand. The cortex is wide and composed of thin-walled cells; the middle area is more or less lacunar, and the outer layers of the stem seem to be of the same nature as those of $a$ stems. The corresponding petioles have also a wide cortex, and a reduced xylem strand which is always monarch.

\section{The Significance of the Occurrence of $a$ and $\beta$ types, p. 553 .}

It is probable that the differences of structure between the $a$ and $\beta$ types throw some light on the autecology of Rachiopteris cylindrica, which, it is suggested, was amphibious, $a$ and $\beta$ plants being respectively its land and water ecads.

$$
\text { 4. Relationships, p. } 554 \text {. }
$$

$R$. cylindrica seems to be closely allied to Botryopteris antiqua, 
B. ramosa, and $B$. hirsuta. So far as the foliar trace is concerned, the four species form a progressive series from the relatively primitive $B$. antiqua to the tridentate types, $R$. cylindrica representing an intermediate term. $B$. forensis does not appear to be very nearly related to this group of British species.

\title{
5. The Primitiveness of the Stelar Condition, p. 56r.
}

Typical steles of $R$. cylindrica show some divergence from the primitive condition, whether this is considered to be an endarch or an exarch protostele, or an asterostele.

\section{The Homology of the Leaf, p. 562 .}

The method of separation of the foliar trace in $R$. cylindrica affords support to the view that stem and leaf represent homologous branches of a primitively undifferentiated system.

\author{
UNiversity COLlege, \\ LONDON. \\ May, I9I5.
}

\section{EXPLANATION OF PLATES XXVI AND XXVII.}

$p x_{.}=$protoxylem $; x i .=$ inner wood $; x o .=$ outer wood $; a m x_{.}=$adaxial metaxylem $;$st. $=$ sieve-tubes $; p c_{0}=$ pericycle $; e_{0}=$ endodermis $; i c_{0}=$ inner $\operatorname{cortex} ; m c_{0}=$ middle cortex $; o c_{0}=$ outer cortex; $l_{0}=$ lacunae of middle cortex $c c_{0}=$ cavities of outer cortex $; t_{0}=$ root-trace $; l_{\text {. }}=$ = leaftrace $; b_{0}=$ branch stele $;$ par $r_{0}=$ parenchyma $; s .=$ stem $; p_{0}=$ petiole.

\section{PLATE XXVI。}

\section{Rachiopteris cylindrica.}

Fig. I. A typical $a$ stem, showing the mesarch protoxylem groups, and the slight differentiation of the internal wood. Note the somewhat concentric inner layers of the cortex; the thin-walled crushed cells composing the outer cortex, and the cavities in this layer. $\times 3^{2}$. (From Q 53 I, Cash collection.)

Fig. 2. A centrarch $a$ stem. $\times 27 . \quad$ (From $\mathrm{K}$ 2I $d$, University College, London.)

Fig. 3. A $\beta$ stem, showing the small stele, with central protoxylem, and the wide cortex of thin-walled cells. At $r$, a root has just passed out; in the cortex is a small leaf-trace; at $l$, the lacunar structure of the middle cortex is shown. $\times 27$. (From K 2I $d$, University College, London.)

Fig. 4. A $\beta$ stem, in which the middle cortex possesses large lacunae. The stele of this stem does not show the typical condition, as it possesses two protoxylem groups. $\times 36$. (From Q ro3, Cash collection.)

Fig. 5. An $a$ stem in which the stele is preparing for dichotomy. The branch-stele is slightly smaller than the parent stele; it possesses two protoxylem groups and some adaxial metaxylem (cf. Fig. 6, in which the leaf-trace has no adaxial metaxylem). $\times 4^{0}$. (From K2I $n$, University College, London.)

Fig. 6. An $a$ stem preparing for leaf-production. Separating parenchymatous cells are present immediately in front of the single protoxylem of the leaf-trace (cf. Fig. 5). $\times 40$. (From K $20 k$, University College, London.)

Fig. 7. A later stage of the $\beta$ stem and leaf-trace shown in Fig. 3 ; both stem and petiole possess a small stele, and wide cortex. $\quad \times 2 \%$. (From K $2 \mathrm{I} e$, University College, London.) 
Fig. 8. A $\beta$ stem just above dichotomy of the stele; each branch has only one protoxylem group. A root $r$ is passing through the cortex; the crushed outer cortex is indicated at several points. $\times 32$. (From Q I05, Cash collection.)

Fig. 9. A $\beta$ stem preparing for dichotomy, immediately above the level of leaf-trace production. The middle cortex is much crushed. $\times 5^{8} . \quad$ (From K 2 I $q$, University College, London.)

\section{PLATE XXVII.}

Rachiopteris cylindrica.

Fig. I. The adaxial margin of the bundle in an a petiole just above the separation of the latter from the stem. The anterior metaxylem appears to be breaking down, and the protoxylem is indefinite. Note the crushed phloem cells $\left(p / l_{0}\right)$, and the transverse section of the pits $(p t$.$) on the$ tracheide walls. $\times 40$. (From slide 302.6 in Dr. Gordon's collection.)

Fig. 2. A petiolar bundle passing through the cortex of a $\beta$ stem. Note the single protoxylem group, and the imperfectly-lignified metaxylem. $\times 200$. (From $\mathrm{K} 2 \mathrm{I} r$, University College, London.)

Fig. 3. The stele of a diarch root, showing the pitted appearance of the endodermis. Certain of the cells appear to be less resistant than the others; note particularly a cell $a$ in the neighbourhood of one of the protoxylem groups. $\quad \times 200 . \quad$ (From $\mathrm{K}_{21} \mathrm{r}$, University College, London.)

Fig. 4. A large $a$ stem, showing the origin of two roots. $\times 40$. (From 302.6, Dr. Gordon's collection.) 


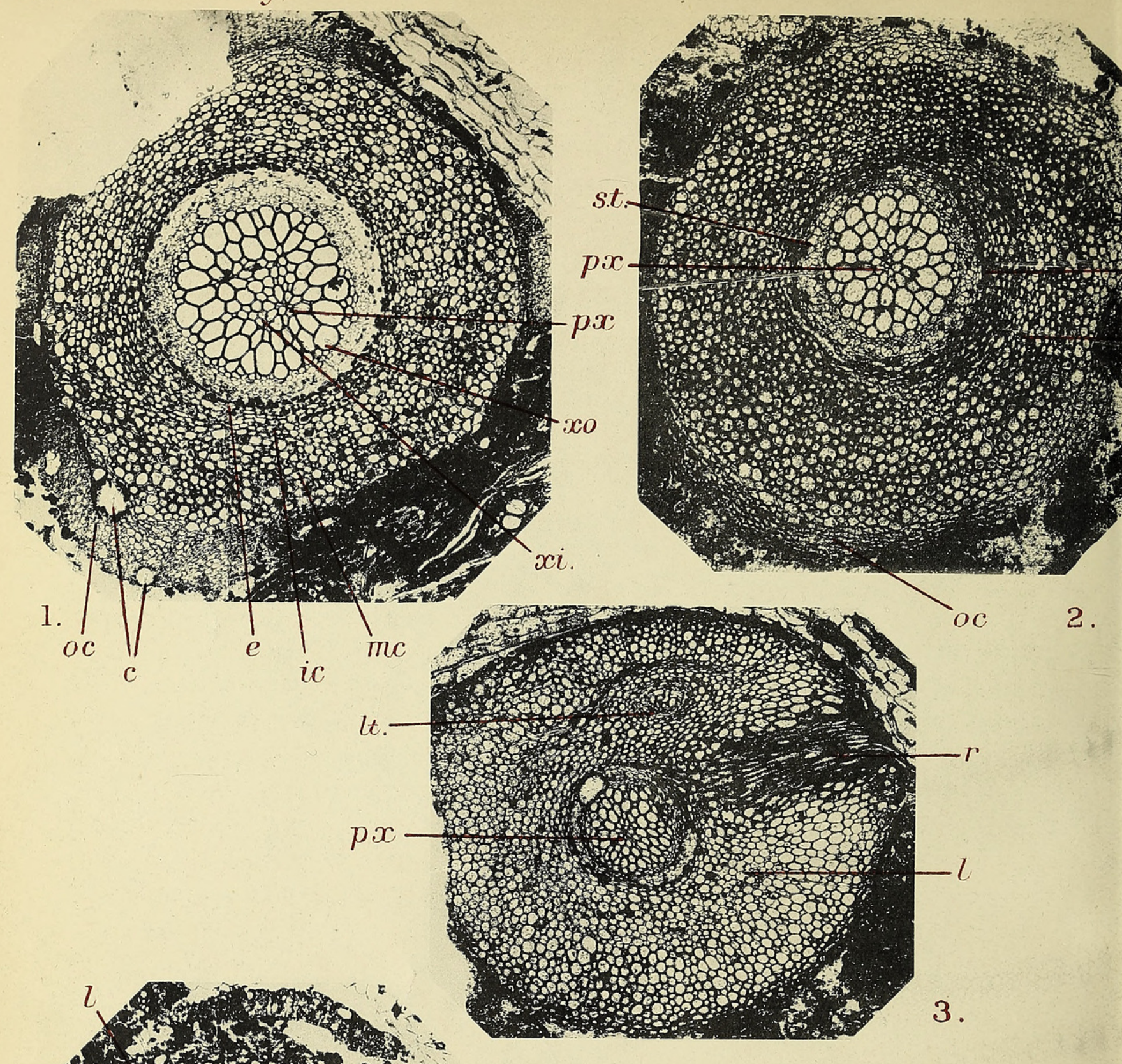

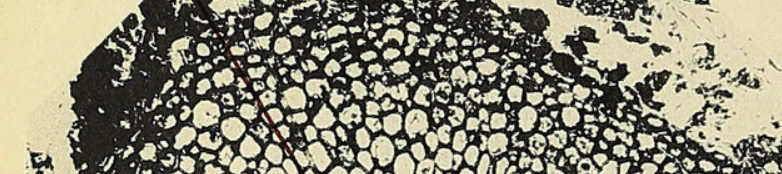

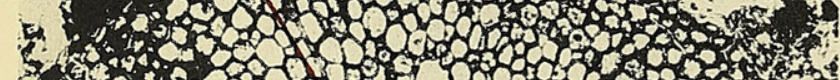

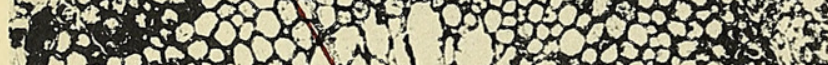

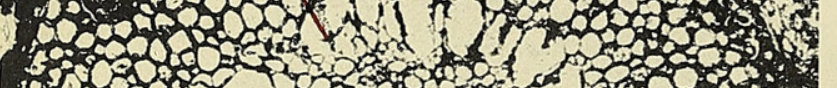
0201 Hon

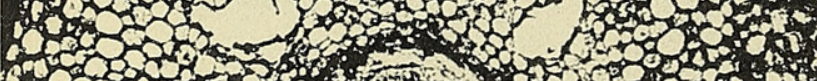

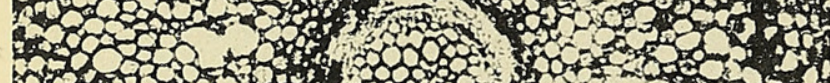
2030 , 1350 .

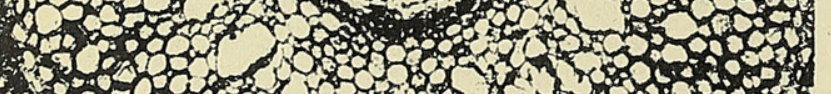
-

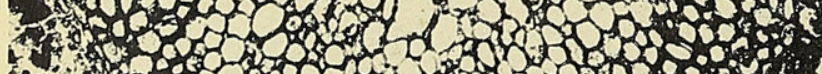

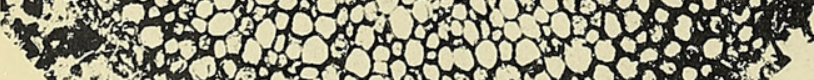

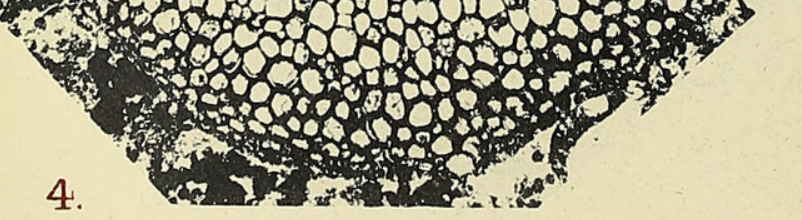

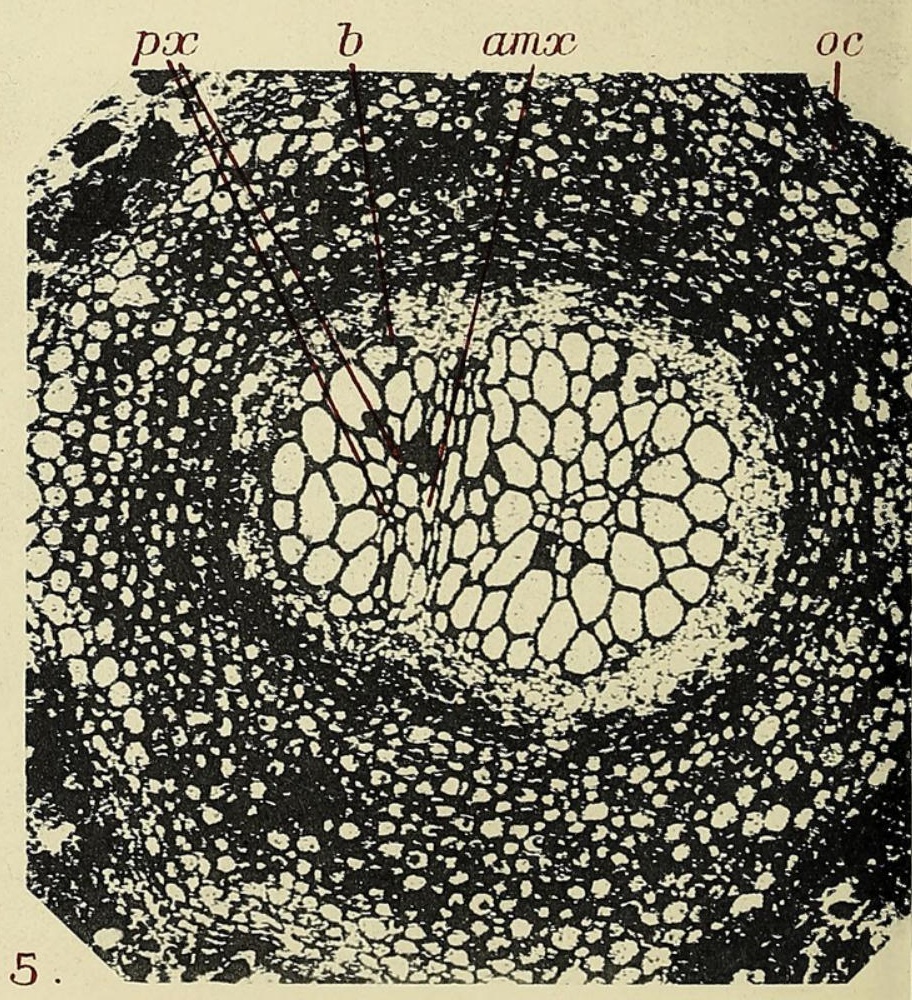




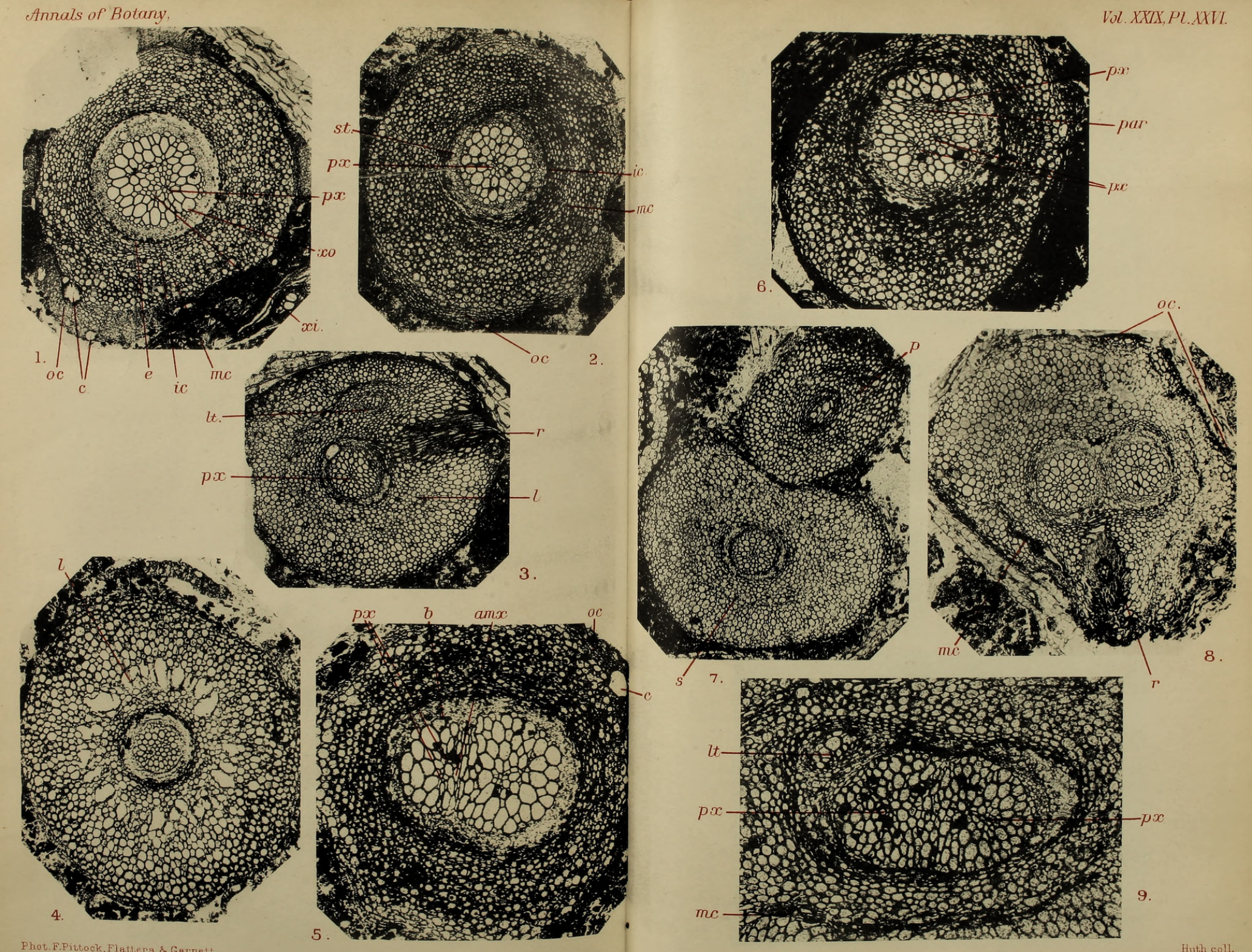


Anuals of Botany.

Vol. XXIX,I'L. IXUII.
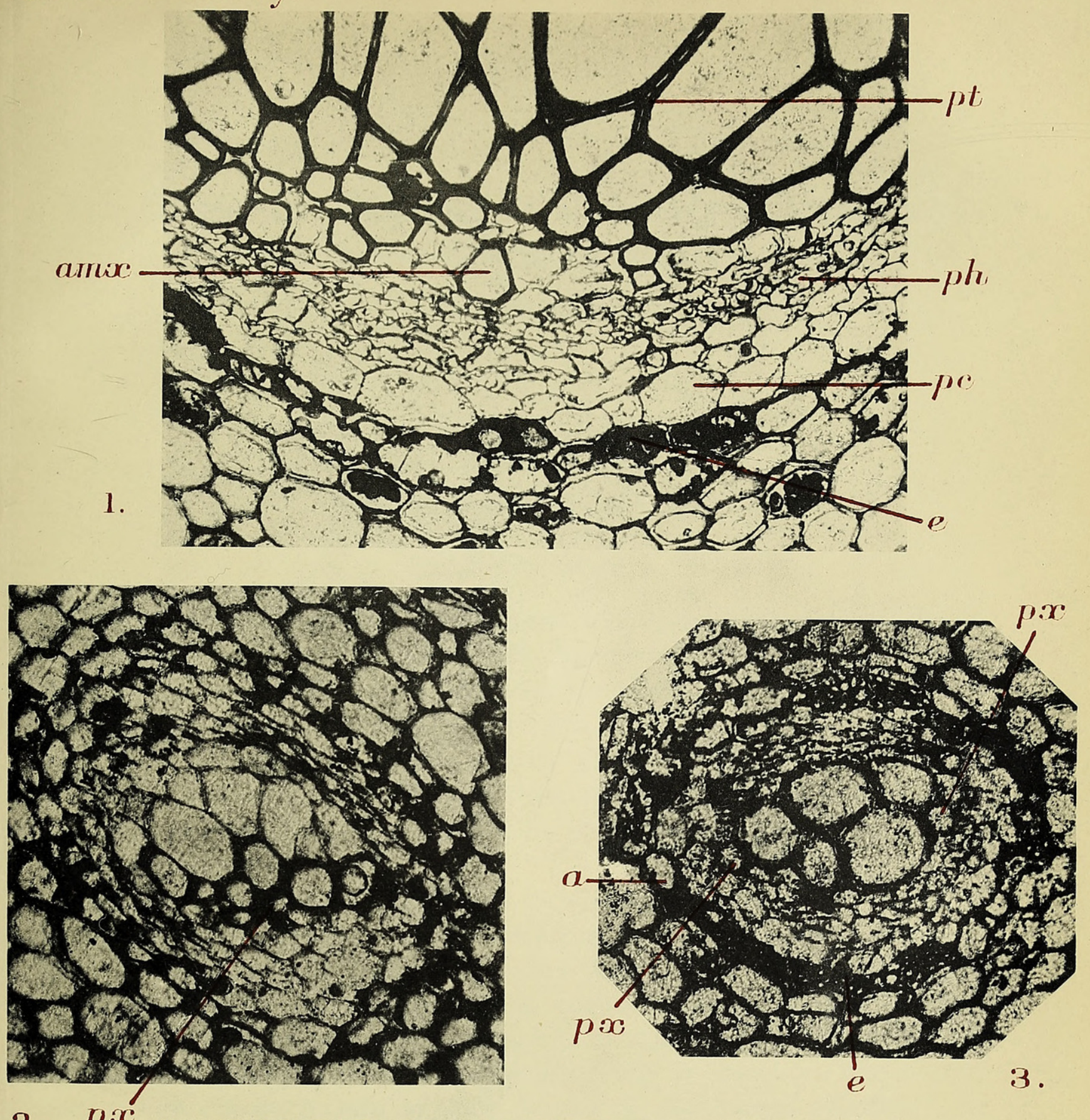

2. $p x$

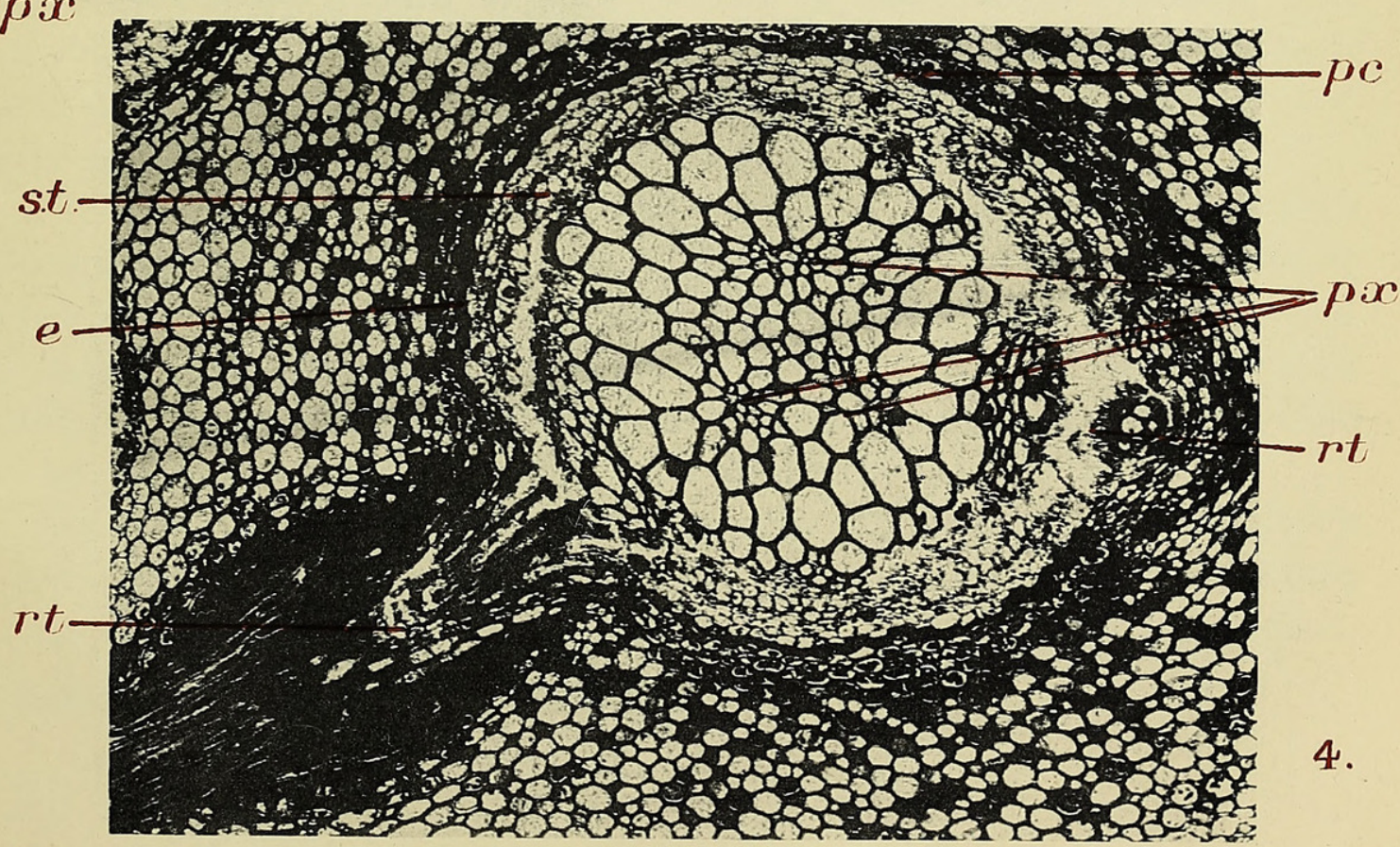




\section{$2 \mathrm{BHL}$ Biodiversity Heritage Library}

Bancroft, Nellie. 1915. "A contribution to our knowledge of Rachiopteris cylindrica, Will." Annals of botany 29, 531-565. https://doi.org/10.1093/oxfordjournals.aob.a089563.

View This Item Online: https://www.biodiversitylibrary.org/item/243629

DOI: https://doi.org/10.1093/oxfordjournals.aob.a089563

Permalink: https://www.biodiversitylibrary.org/partpdf/320080

\section{Holding Institution}

Smithsonian Libraries

\section{Sponsored by}

Biodiversity Heritage Library

\section{Copyright \& Reuse}

Copyright Status: Not in copyright. The BHL knows of no copyright restrictions on this item.

This document was created from content at the Biodiversity Heritage Library, the world's largest open access digital library for biodiversity literature and archives. Visit BHL at https://www.biodiversitylibrary.org. 